\title{
Bidirectional bedform fields at the head of a submarine canyon (NE Atlantic).
}

Claudio Lo Iacono ${ }^{1,2 *}$, Jorge Guillen ${ }^{1}$, Queralt Guerrero ${ }^{1}$, Ruth Duran ${ }^{1}$, Catherine Wardell $^{2}$, Rob Hall ${ }^{3}$, Tahmeena Aslam ${ }^{3}$, Gareth Carter ${ }^{4}$, Jenny Gales ${ }^{5}$, Veerle A.I. Huvenne ${ }^{2}$

${ }^{1}$ Marine Sciences Institute, Spanish National Research Council, Paseo Maritimo de la Barceloneta 37-49, 08003 Barcelona, Spain

2 National Oceanography Centre, University of Southampton, Waterfront Campus, Southampton, United Kingdom

3 Centre for Ocean and Atmospheric Sciences, School of Environmental Sciences, University of East Anglia, Norwich Research Park, Norwich, United Kingdom

${ }^{4}$ British Geological Survey, The Lyell Centre, Research Avenue South, Edinburgh, United Kingdom

5 University of Plymouth, School of Biological and Marine Sciences, Drake Circus, Plymouth, PL4 8AA, United Kingdom

*: corresponding author. E-mail address: loiacono@icm.csic.es

ABSTRACT

2 Submarine canyons are known to force ocean mesoscale circulation and local hydrodynamics. Alternate up- and down-canyon near-bottom flows have been widely documented along the upper reaches, connecting the canyon heads with the contiguous outer shelves and vice versa. Nonetheless, we still miss clear evidence of bedform fields expressing these complex patterns. In this study, through a multi-scale analysis in both space and time, we document rare asymmetric bedforms, up to $880 \mathrm{~m}$ long and $10 \mathrm{~m}$ high, developing within a depth range of $168-220 \mathrm{~m}$ at the head of the Whittard Canyon (NE Atlantic). One field of well-developed sandwaves has an atypical up-slope asymmetry, with the steeper slope facing the shallower regions of the shelf, and 
contrasting with surrounding down-slope sandwaves facing the canyon. The bedforms are interpreted to represent both up-slope and down-slope bottom currents connecting the upper reaches of the canyon to the outer shelf on the southern Celtic Margin, in the Bay of Biscay. The sandwaves were surveyed with shipboard Multibeam bathymetry (5 $\mathrm{m}$ grid cell resolution), AUV sidescan sonar $(0.15 \mathrm{~m}$ grid cell resolution) and ROV footage, and sampled with three ROV-mounted vibro-cores and two box-cores. Sidescan sonar mosaics groundtruthed by ROV footage and sediment samples show with unprecedented detail spectacular trains of fresh overprinting megaripples, previously undocumented sand peaks and bowl-shaped depressions on the crests of the tallest sandwaves. Differences in sedimentary settings and benthic habitats indicate that these features are currently active in particularly dynamic areas, allowing for very slow migration of sandwaves. Modelling of the internal tide regime together with concurrent hydrographic observations suggest large-amplitude semi-diurnal internal tides, possibly transitioning to asymmetric internal bores, as the main mechanism maintaining the mapped up-slope sandwaves. This work highlights the importance of uncommon sediment dynamics in canyon head environments and adds insight to the traditional notions of gravity-driven processes, being dominant in these environments, envisaging implications for improving geo-hazard assessment of mobile substrates and quantification of offshore sediment and carbon fluxes.

51 Keywords: Bedforms, seafloor mapping, marine robotics, geomorphology, submarine canyons, internal tides

\section{1. INTRODUCTION}

54 The increasing detail of high-resolution mapping of bedform fields across several continental shelves around the world is regularly revealing uncommon morphological 
patterns related to complex and variable sedimentary and hydrodynamic regimes. For example, observations on coastal and inner shelf settings report sandwave fields migrating in opposite directions related to intricate hydrodynamic patterns (Van Landeghem et al., 2012; Jiang and Lin, 2016). The dynamics of these bedforms are

60 generally controlled by the interplay of storm-forced currents and steered residual tidal 61 flows, acting over a variable local geomorphology (Boe et al., 2009; Van Landeghem et al., 2012).

However, present-day activity of bedforms on sediment-starved outer shelf settings, deeper than $100 \mathrm{~m}$ and far from modern fluvial sediment inputs, is still poorly understood, mainly due to the lack of detailed seafloor mapping and long-term hydrodynamic observations. In these settings, which are less sensitive to coastal hydrodynamics and storm-induced flows, sandwave dynamics are mainly related to along-shelf geostrophic circulation, generally reactivating relict sandy deposits developed during previous sea-level stages (Lo Iacono et al, 2010; Rovere et al., 2019). These hydrodynamic patterns can become more complex in the vicinity of shelf-incising submarine canyons (Allen and Durrieu de Madron, 2009; Li et al., 2019). The upper reaches of canyons are major conduits for down-slope gravitational flows funnelling sediments to the deep-sea (Piper and Normark, 2009; Paull et al., 2011; Azpiroz-Zabala et al., 2017), and may also promote up- and down-slope sediment transport related to amplified internal waves (Allen and Durrieu de Madron, 2009; Puig et al., 2013; Li et al., 2019). However, we are still missing clearly documented evidence of bedform field migration in relation to such hydrodynamic processes, connecting the canyon head to the shallower adjacent shelf and vice versa. Yet, these findings may have relevant implications in ensuring the long-term integrity of offshore infrastructures (e.g. windfarm foundations, subsea pipelines, and tele-communication cables) close to mobile 
81 substrates, in addition to better defining the patterns of organic and oxygen rich fluxes

82 across continental margins (Ahmerkamp et al., 2015). During the JC125 CODEMAP

83 Cruise, aimed to map and quantify complex deep-sea habitats of the Whittard Canyon

84 (NE Atlantic), we used a combination of routine and advanced marine robotic

85 technologies (shipboard / Autonomous Underwater Vehicle (AUV) mapping, Remotely

86 Operated Vehicle (ROV)-mounted vibro-cores, box-cores, ROV footage), to document

87 atypical bedform fields, mapped on the Celtic outer shelf between 168 and $220 \mathrm{~m}$ water

88 depth, showing contrasting geomorphological patterns at the head of the eastern canyon

89 branch (Fig. 1). We: 1) describe the morphology and sedimentology of different

90 superimposed bedforms, 2) examine the role of the Whittard Canyon in their generation

91 and evolution, with specific reference to internal tides, and 3) discuss their long- and

92 short-term dynamics.

\section{2. GEOLOGICAL AND OCEANOGRAPHIC SETTING}

94 The Celtic margin is a passive continental margin that extends WNW-ESE between the

95 Goban Spur and the Berthois Spur (Bourillet et al., 2006, Fig. 1). The continental shelf, 96 connected with the English Channel, is up to $500 \mathrm{~km}$ wide and connects with a steep

97 structurally controlled continental slope (average $8^{\circ}$ ). The geomorphology of the shelf is irregular, with around 45 linear sand ridges, 40 to $180 \mathrm{~km}$ long, crossing the shelf

99 roughly perpendicular to the continental slope between $100 \mathrm{~m}$ and $200 \mathrm{~m}$ water depth

100 (Bouysse et al., 1976; Praeg et al., 2015) (Fig. 1a). These ridges correspond to

101 glacigenic sand banks formed between 20 and 12 ka BP (Pantin and Evans, 1984;

102 Scourse et al., 2009) and have been partially reworked by tidal flows during the last

103 marine transgression (Berné et al., 1998; Reynaud et al., 1999). The Whittard Canyon,

$104200 \mathrm{~km}$ long, is the largest of several submarine canyons incising the Celtic margin

105 (Mulder et al., 2012; Amaro et al., 2016). It extends from the shelf-edge, $200 \mathrm{~m}$ deep, to 
106 the base of the continental slope, $4500 \mathrm{~m}$ deep (Bourillet et al., 2006; Mulder et al.,

107 2012; Fig. 1a). Four dendritic V-shaped branches are controlled by persistent headward

108 erosion, which creates sub-vertical walls with exposed Cretaceous to Pleistocene

109 sedimentary successions (Carter et al., 2018 and references therein). The sandwaves

110 presented in this study were previously interpreted as relict features active during the

111 Last Glacial Maxima (Cunningam et al., 2005). Two hundred km SE from the sandwave

112 field presented here, up to $1 \mathrm{~km}$ long active sandwaves were described on the La

113 Chapelle Bank, and interpreted as being controlled by barotropic (surface) tidal residual

114 velocities, although baroclinic (internal) tides could play a role in their dynamics in

115 proximity of the shelf-edge (Heathershaw and Codd, 1985).

116 Tidal currents in the Celtic Sea region are dominated by semi-diurnal (twice daily)

117 constituents and $75 \%$ of the kinetic energy can be attributed to the principal lunar semi-

118 diurnal constituent $\left(\mathrm{M}_{2}\right)$ (Pingree, 1980). Along the Celtic margin, barotropic tidal

119 currents vary in magnitude over the spring-neap cycle, from $0.2 \mathrm{~m} \mathrm{~s}^{-1}$ during neaps to

$120 \quad 0.5 \mathrm{~m} \mathrm{~s}^{-1}$ during spring (Sharples et al., 2007). The semi-major axis of the $\mathrm{M}_{2}$ tidal

121 ellipse is orientated NE-SW, across the slope (Pingree et al., 1999). This tidal ellipse

122 orientation, along with a density stratified water column, allows the generation of

123 internal waves with tidal frequencies (internal tides).

124 The highly corrugated slopes of the upper canyon and outer shelf generate a complex

125 internal tide field (Vlasenko et al., 2014) and on-shelf propagating waves are dissipated

126 close to the shelf-edge (Hopkins et al., 2014). Strong tidal currents and breaking internal

127 waves within Whittard Canyon are expected to enhance the turbulent mixing of physical

128 and biogeochemical properties through the water column, especially near the canyon

129 heads, and may also generate near-bed internal bores, which increase sediment 
130 resuspension and along-canyon transport (Amaro et al., 2016; Hall et al., 2017; Aslam

131 et al., 2018).

\section{3. MATERIAL AND METHODS}

133 Most of the dataset used for this study has been collected during the JC125 Cruise,

134 carried out in 2015 aboard the RRS "James Cook", in the frame of the CODEMAP 135 Project ("Complex Deep-sea Environments: Mapping habitat heterogeneity As Proxy 136 for biodiversity" - ERC Starting Grant). The shipboard Multibeam (MB) system was the $137100 \mathrm{kHz}$ Kongsberg EM710, producing a Digital Terrain Model (DTM) at a grid cell 138 resolution of $5 \mathrm{~m}$. An additional $\mathrm{MB}$ dataset, aimed to extend the mapping of bedforms 139 around the area, was collected with the same MB system in 2018 during the JC166 140 Cruise, aboard the RRS "James Cook" (part of the NERC funded CLASS programme).

141 Two AUV "Autosub6000" Side Scan Sonar (SSS) missions and one MB survey were 142 performed during JC125. AUV navigation was achieved using a RDI Doppler Velocity 143 Log (DVL) inertial navigation system (dead-reckoning) linked to a GPS fix before 144 descending and a Ultra-Short Baseline (USBL) position at the start of the mission. To 145 minimize the AUV drift during the dives, its position was also recalculated at the end of 146 each mission by USBL if the ship was in the vicinity, or by GPS surface location once 147 emerged.

148 The AUV-SSS was the $410 \mathrm{kHz}$ EdgeTech FS2200. SSS mosaics were produced at a 149 grid cell resolution of $15 \mathrm{~cm}$ using the software PRISM, developed at the National 150 Oceanography Centre (NOC). The AUV-MB system was a $200 \mathrm{kHz}$ Kongsberg 151 EM2040, allowing for the production of a DTM at a grid cell resolution of $2 \mathrm{~m}$. The 152 ROV "ISIS" performed two dives on a western region where AUV-SSS was previously 153 acquired, to groundtruth the area using an integrated vibro-corer. The ROV-vibro-core 154 strongly improved the precision of sampling operations, in parallel with a visual 
155 groundtruth of the local habitats. ROV navigation was achieved using a Sonardyne

156 USBL, in parallel with Doppler dead-reckoning calculated through a RDI DVL. Three

157 ROV vibro-cores were collected from different bedform settings (sand peak: VC_129,

158 sandwave stoss: VC_131-1, sandwave trough: VC_131-2) with penetrations of $98 \mathrm{~cm}$,

$15974 \mathrm{~cm}$ and $43 \mathrm{~cm}$ respectively. The ROV camera was an OKEANOS Insite Mini Zeus

160 HD 1920 x 1080, equipped with two parallel laser pointers $10 \mathrm{~cm}$ apart. Two additional

161 box-cores were collected (sandwave stoss: BC_147, sandwave crest: BC_148) and sub-

162 sampled, resulting in core lengths of $19 \mathrm{~cm}$ and $20 \mathrm{~cm}$ respectively. Samples from

163 sediment cores were collected every 5 centimetres and dried at $80^{\circ} \mathrm{C}$ for 24 hours. The

164 sediment fraction finer than $2000 \mu \mathrm{m}$ was examined using an LA-950V2 laser scattering

165 particle size distribution analyser (HORIBA), while the coarser fraction was sieved for

1666000,4000 and $2000 \mu \mathrm{m}$.

1671270 bathymetric transects orthogonal to the sandwave crests and spaced $20 \mathrm{~m}$ each

168 other were extracted from the bathymetric grids, and morphometric indices (wavelength

$169 \lambda$, height $\mathrm{h}$, asymmetry index (AI), migration rates) calculated. The sandwave

170 wavelength $(\mathrm{L}=\mathrm{L} 1+\mathrm{L} 2)$ is defined as the distance from trough to trough, compensated

171 for slope inclination $\alpha$ (Fig. 2). The sandwave height (h) is calculated as the orthogonal

172 from the highest point of the bedform (crest) to the baseline (Fig. 2). Following the

173 method of Knaapen (2005), the asymmetry index (AI) is defined as the difference of the

174 distances between the crest and the upslope and downslope troughs, divided by the

175 wavelength (L2-L1)/L (Fig. 2). Positive and negative AI values are indicative of

176 downslope and upslope asymmetry respectively. Sandwaves with AI between -0.2 and

1770.2 were considered as symmetric. Coordinates and elevations were obtained every 20

$178 \mathrm{~m}$ along each transect. Hull-mounted MB bathymetry (15 m grid cell resolution)

179 acquired in 2000 by the Geological Survey of Ireland in the frame of the INFOMAR 
180 Project was compared to the JC125 MB dataset (5 m grid cell resolution) to assess the 181 migration rate of the mapped sandwaves over a period of 15 years.

\section{4. RESULTS}

\section{$184 \quad 4.1$ Geomorphology of the Whittard bedforms}

185 The sandwave field was mapped across a 25 by $9 \mathrm{~km}$ wide sector of the outer shelf, 186 with a $0.1^{\circ}$ gradient on average, within a depth range of $164-210 \mathrm{~m}$ (Fig. $\left.1 \mathrm{~b}\right)$. The outer 187 shelf is incised between $200 \mathrm{~m}$ and $220 \mathrm{~m}$ by the heads of two adjacent tributaries of the 188 eastern branch of the Whittard Canyon, defined here as western and eastern tributaries 189 (Fig.1b). The average wavelength of the sandwaves is $367 \mathrm{~m}$, with a maximum of 880 $190 \mathrm{~m}$ (Fig. S1). Their height displays an average value of $4 \mathrm{~m}$, with a maximum of $10.4 \mathrm{~m}$

191 (Fig. S1). All sandwaves are approximately parallel to the shelf-edge, directed 192 perpendicular to the axes of the two tributaries (Fig. 1b).

193 Asymmetry is significantly different between the regions of mapped sandwaves (Fig. 3).

194 Sandwaves adjacent to the western tributary display up-slope asymmetric trends, with 195 average AI values of -0.3 and minimum of -0.95 (Fig. S1). At an average depth of 190

$196 \mathrm{~m}$, these sandwaves become symmetric for a limited portion of the shelf and become 197 down-slope asymmetric at shallower depths (Fig. 3). In the transition between up-slope 198 and down-slope asymmetry, all three trends can coexist on the same sandwaves, 199 reflecting convergent sediment transport directions (Fig. 3). Down-slope asymmetry 200 becomes dominant towards the easternmost sector of the shelf, where AI values display 201 an average of 0.29 , increasing up to 0.9 (Fig. 3, Fig. S1). Two sub-areas (named western 202 and eastern fields hereafter) located $10 \mathrm{~km}$ apart in front of the western and eastern 203 tributaries, were mapped at high resolution with the AUV (Figs. 4-7, Fig. S2). 
204 Furthermore, the western field was groundtruthed with ROV visual observations, vibro205 cores and box-cores.

207 Western field - The western field displays a sandwave train between $188 \mathrm{~m}$ and $240 \mathrm{~m}$ 208 water depth (Fig. 4). Their average wavelength is $387 \mathrm{~m}$, with a maximum value of 671 $209 \mathrm{~m}$, the average height being $5.2 \mathrm{~m}$, with a maximum value of $10.4 \mathrm{~m}$ (Fig. S3). The 210 western sandwaves are up-slope asymmetric (average value AI: -0.33, minimum value: 211 -0.94) (Fig. S3), with their asymmetry decreasing towards the shallower sectors, 212 suggesting a net sediment transport directed from the canyon head to the outer shelf 213 (Fig. 3). Crests, approximately parallel and occasionally bifurcated, are mostly NW-SE 214 oriented $\left(120^{\circ}\right)$ and up to $10 \mathrm{~km}$ long (Fig. 3). AUV-SSS mapping revealed that 2D 215 megaripples and complex 3D features occur on the entire western field (Figs. 4, 5). 216 Almost all the megaripples display an up-slope asymmetry, coherent with the 217 sandwaves on which they are superimposed (Fig. 8a).

218 At the head of the western tributary, at a depth between $205 \mathrm{~m}$ and $230 \mathrm{~m}$, a dense 219 network of asymmetric megaripple trains occurs with a height of up to $1 \mathrm{~m}$ and a 220 variable wavelength ranging between $10 \mathrm{~m}$ and $45 \mathrm{~m}$ (Figs. 4, 5a). Along this sector, megaripples organize in a herringbone pattern with a bimodal orientation: NW-SE $\left(140^{\circ}-160^{\circ}\right)$ and WNW-ESE $\left(100^{\circ}-110^{\circ}\right)$ (Fig. 4). Moreover, megaripples here are occasionally interrupted by longitudinally aligned sand peaks, alternating crests and 224 troughs for up to $110 \mathrm{~m}$ long in a NE-SW direction $\left(47^{\circ}-60^{\circ}\right)$ (Fig. 5a). Towards 225 shallower depths, megaripple wavelength decreases, ranging between $6 \mathrm{~m}$ and $14 \mathrm{~m}$, with the longest occurring close to the sandwave crests, and their height being $0.5 \mathrm{~m}$ on average (Fig. 5b). Their main orientation is NW-SE $\left(130^{\circ}-160^{\circ}\right)$, forming a clockwise angle of $10^{\circ}-40^{\circ}$ offset with the sandwave crests (Figs. 4, 5). Megaripples are generally 
absent on a low-energy "shadow zone" sheltered by the sandwave crests, in some case

230 displaying low backscatter facies suggesting fine sediment textures (Figs. 5b, c, d). The

231 shadow zone covers the troughs and which becomes progressively larger moving up-

232 slope (Fig. 4). In parallel, moving up-slope, megaripples concentrate exclusively on the

233 sandwave crests, losing their relief and lateral continuity (Figs. 4, 5c, 8a). The tallest

234 sandwaves of the western field display on their crests roughly circular depressions

235 regularly and closely spaced, $10-15 \mathrm{~m}$ wide, and up to $0.4 \mathrm{~m}$ deep (Fig. 5b). To our

236 knowledge, these intriguing features, defined as bowl-shaped depressions, have never

237 been described in previous works.

239 Eastern field - Sandwaves of the eastern field occur at a depth between $178 \mathrm{~m}$ and 201

$240 \mathrm{~m}$, where they are interrupted at the shelf margin, incised by the head of the eastern

241 tributary canyon (Fig. 1b, Fig. S2). They display an average wavelength of $324 \mathrm{~m}$, with

242 a maximum value of $574 \mathrm{~m}$, and an average height of $3.1 \mathrm{~m}$, with a maximum value of

$2437.5 \mathrm{~m}$ (Fig. S3). The eastern sandwaves are NW-SE oriented (average orientation:

$244134^{\circ}$ ), their crests being linear or slightly sinuous. They present a positive asymmetry

245 index (average AI: 0.12, maximum AI: 0.78) (Fig. S3), being directed towards the head

246 of the tributary canyon and contrasting with the opposite trend of the western field (Fig.

247 S2). AUV-SSS and MB data collected on the eastern field display a dense network of 248 superimposed megaripple trains, 5 to $15 \mathrm{~m}$ long and up to $0.5 \mathrm{~m}$ high (Figs. 6,8b, Fig.

249 S2). These megaripples are observed on the sandwave stoss sides and close to the crests,

250 and are less frequent along the trough (Figs. 7a, 8b). They develop in a similar direction

251 to the sandwaves crests (NW-SE), or offset by a clockwise angle of $20-30^{\circ}$ with them

252 (Fig. 6). Their morphology ranges between slightly symmetrical to asymmetrical, with

253 their asymmetry increasing close to the sandwave crests and being consistent with the 
sandwaves migrating towards the canyon (Fig. 8b). This is also reflected by the high backscatter facies on some of the crests, suggesting coarse sediments controlled by high-energetic hydrodynamics, changing to low backscatter on the following downslope

257 lee, coinciding with fine-sediment in sheltered low-energy environments (Figs. 7b, 258 7b1). The crests of the most pronounced sandwaves in the eastern field display in most 259 cases an uncommon two-fold morphology in plan view, consisting of two, or three, 260 megaripple crests running parallel to the sandwave crest (Figs. 6, 7b). The two-fold crests can laterally pass to 3D geomorphologies, defined here as tear-drop shaped lobes, 0.4-0.8 $\mathrm{m}$ deep, stretching for 30 to $40 \mathrm{~m}$ along the direction of the sandwave crests

263 (Figs. 6, 7b).

264 Finally, a dense network of asymmetric megaripples directed towards deeper depths has

265 been mapped on the canyon head (Figs. 7c, d). These megaripples are 5 to $20 \mathrm{~m}$ long 266 and 0.5 to $0.8 \mathrm{~m}$ high. In limited areas of this region, megaripples merge their crests to

267 form 3D sub-circular features, 20-40 m wide and 0.5-1 m deep (Figs. 7c, d).

\section{$268 \quad 4.2$ Groundtruthing data}

269 Sediment cores

270 Vibro-cores (VC) and box-cores (BC) reveal a dominant sandy grain size, although their spatial variability reflects different morpho-sedimentary environments within the sampled bedforms. The core collected on a sand peak of the western field (VC_129,

273 Fig. 9a), consists of well sorted yellow medium sands throughout the entire $98 \mathrm{~cm}$ long 274 core, except for an increase to coarse and very coarse sands between 20 and $30 \mathrm{~cm}$ 275 below the surface (Fig. 9). The core does not present any stratification or internal structure. Two cores were collected on the stoss side (VC_131-1) and in the trough

277 (VC_131-2) of the same sandwave (Fig. 9b). On the sandwave stoss side, where 278 superimposed megaripples are evident on the SSS mosaic (Fig. 9b), VC_131-1 consists 
of greenish muddy layers for the first $3 \mathrm{~cm}$, coarsening to well sorted brownish medium sands until the depth of $38 \mathrm{~cm}$ (Fig 9). Below this level, sediment grain size changes to moderately sorted medium sands with armouring gravelly layers consisting of scattered broken shells, 1 to $2 \mathrm{~cm}$ large, down to the base of the core, at $74 \mathrm{~cm}$ (Fig. 9). In the trough of the same sandwave, VC_131-2 shows bioturbated sediments with a finer

284 sediment texture, consisting of greenish poorly sorted muddy sands, becoming stiff 285 from $35 \mathrm{~cm}$ to the base of the core, $43 \mathrm{~cm}$ deep (Fig. 9). Coarse broken shells occur between 12 and $15 \mathrm{~cm}$ and a layer of well laminated bioclasts (mainly Scaphopoda) is evident between 28 and $31 \mathrm{~cm}$, sustained by a matrix of medium and fine sands (Fig. 9). Two box-cores were collected in the same region (Fig. 9). BC_147, located on the sandwave crest, is dominated by well sorted and winnowed yellow medium sands, without any internal structure across its length $(21 \mathrm{~cm})$. BC_148, $18 \mathrm{~cm}$ deep, is located in the trough of the sandwave, nearby VC_131-2 (Fig. 9), and consists of strongly bioturbated poorly sorted greenish silty fine sands. Several burrows inhabited by worms were observed on the top and within the first $10 \mathrm{~cm}$ of this box-core (Fig. 9).

\section{Seabed video observations}

296 The ROV videos collected during the vibro-core operations show different aspects of

297 the seafloor in the sampled regions. The sampled sand peak is fully covered by 298 superimposed sharp-crested up-canyon asymmetric ripples and almost a total absence of 299 benthic fauna has been observed, except for a few sparse holothurians (Fig. 10a). 300 Relevant changes were observed in the ROV transect moving from VC_131-1 to 301 VC_131-2. The stoss region (location of VC_131-1) was characterized by faded up302 slope ripples and by the presence of mainly mobile fauna (starfish, crabs, holothurians, 303 fishes) (Fig. 10b). Getting close to the sandwave crest, fresh ripples were observed 
304 superimposed on the megaripples, displaying the same orientation and asymmetric

305 trends (Figs. 10c, d). Similarly to the location of VC_129, very few organisms were 306 observed on the ROV video when approaching the crest (Figs. 10c, d). Down-slope of

307 the sandwave crest, ripples tended to fade out in the trough, coinciding with the region

308 of the SSS mosaic in which megaripples cease to occur. In parallel, bioturbation

309 increased, and several sessile organisms, mainly anemones, were observed at the

310 VC_131-2 sampling location (Fig. 10e).

\section{$312 \quad$ 5. DISCUSSION}

\section{$313 \quad 5.1$ Up-slope and down-slope outer-shelf bedforms around the Whittard Canyon}

314 The application of advanced marine robotic technologies unveiled spectacular fields of

315 bedforms at the head of the Whittard Canyon. Up- and down-slope asymmetric

316 bedforms, spanning centimetre to kilometre scales, reflect the occurrence of peculiar

317 sediment dynamic processes which connect the outer shelf domain with the heads of

318 submarine canyons and vice versa. The bedforms are mainly composed of sandy

319 sediments, which most likely consist of coastal bioclastic deposits produced during

320 previous sea-level lowstands (Scourse et al., 2009) and reworked since the last sea-level

321 transgressive stage until the present day. The distribution, orientation and asymmetry

322 observed on the bedforms surrounding the head of the western tributary suggest that

323 these sandwaves are related to strong up-canyon near-bottom currents which rise up the

324 canyon rim onto the surrounding outer shelf (Fig. 11).

325 We rule out the interpretation of these bedforms as up-slope migrating cyclic steps, as 326 these features are generally controlled by channelized density currents on steep slopes, 327 alternating super and sub-critical flows (Parker, 1996; Paull et al., 2011; Slootman and 328 Cartigny, 2020). None of the above mentioned environmental conditions are observed 
in the study area. The up-canyon migrating 3D megaripples and the alligned sand peaks

330 mapped at the head of this canyon (Figs. 4, 5a) probably reflect the most energetic

331 hydrodynamic regime of the entire study area, requiring up to $1 \mathrm{~m} \mathrm{~s}^{-1}$ fast currents to

332 form (Southard and Boguchwal, 1990). Both the directions of megaripples (NW-SE and

333 WNW-ESE) and of aligned sand peaks (NE-SW) are consistent with along-canyon-axis

334 near-bottom currents, orientated NE-SW.

335 Moreover, the ongoing action of strong up-slope flows is confirmed by the large 336 "shadow areas" on the stoss sides of the sandwaves, often coinciding with low

337 backscatter facies, and by the megaripples superimposed on the sandwaves (SSS 338 observation) (Figs. 5b, c, d), which in turn host fresh ripples (ROV visual observations)

339 (Figs. 10c, d), all of them displaying similar asymmetric trends and particularly 340 complex patterns around the sandwave crests (Figs. 4, 5b,d). The divergence angle of $34120^{\circ}-35^{\circ}$ between megaripple and sandwave crests is probably due to the deflection of 342 local flows induced by the variable geomorphology (Van Dijk and Kleinhans, 2005).

343 Moving away from the canyon head, the intensity of up-slope bottom currents

344 progressively dissipates, with the megaripples fading on the sandwave stoss sides and

345 tending to develop exclusively on their crests (Fig. 4).

346 Up-slope bedform asymmetry ceases at around $190 \mathrm{~m}$ water depth, coinciding with the

347 upper limit of sandwave bifurcations, indicating that the canyon-sourced sediment 348 transport direction is limited to the region surrounding the canyon head (Figs. 3, 11).

349 Shallower and to the side of the canyon head, the sandwaves become symmetric and 350 transition to down-slope asymmetric (Figs. 3, 11). The orientation of down-slope 351 sandwaves coincides with the direction of the regional across-shelf tidal currents, which

352 have a dominant NE-SW direction (Amaro et al., 2016). On the deepest sector of the 353 shelf, at an average depth of $190 \mathrm{~m}$, down-slope sandwaves are interrupted by the head 
of the eastern tributary canyon, which incises the outer shelf deposits (Figs. 3, 6, 11).

355 The superimposed megaripples of the eastern field are equally down-slope asymmetric, controlled by bottom currents directed towards the canyon head (Figs. 6, 7a, b), where intense down-slope gravity currents can generate rounded 3D megaripples (Figs. 6c,d, 11). These bedform fields suggest that the Whittard Canyon is an active conduit for sediment transport processes funnelling coarse sediments down to the deep sea.

5.2 The role of Whittard Canyon in the generation and maintenance of up-slope sandwaves

To our knowledge, this work presents the first extensive seafloor expression of up-slope bottom currents rising over the rim of a submarine canyon onto the outer shelf. Some older works based on low-resolution geophysical datasets have described sandwave dynamics hinting at similar hydrodynamic forcing along the upper reaches of other canyons (Knebel and Folger, 1976; Karl et al., 1986). Seismic records revealed the occurrence of up-slope asymmetric sandwaves at the head of Navariski Canyon (Bering Sea) (Karl et al., 1986) and at the outer shelf adjacent to the head of Wilmington Canyon (US Atlantic margin) (Knebel and Folger, 1976). The sandwaves, perpendicular to the canyon axis, are composed of fine sands and resemble the dimensions of the sandwaves described here. The suggested mechanisms responsible for sandwave migration were in both cases internal waves with a tidal or shorter period, which once

374 channelized along the canyon axis would increase in strength and transport sediments 375 towards the canyon head (Knebel and Folger, 1976; Karl et al., 1986).

376 Barotropic tides over abrupt and sloping canyon morphologies can locally generate

377 internal tides (Hotchkiss and Wunsch, 1982; Hall and Carter 2011), and form up-slope 378 propagating internal tidal bores during critical or near-critical reflection (Dauxois and 
379 Young, 1999; Legg and Adcroft, 2003). These conditions are met when the geometric

380 slope of internal tides (determined by wave frequency, stratification strength, and

381 latitude) is approximately equal to the canyon-axis morphological slope. During near-

382 critical reflection, internal wave energy is trapped near the sloping boundary and

383 typically results in non-linear effects, wave breaking, and, if the forcing internal tide is

384 strong enough, the formation of an internal bore (Hall et al., 2017). Oscillatory down-

385 and up-welling bottom flows with tidal or sub-tidal frequencies strongly increase their

386 intensity along the axis of several well-studied submarine canyons, most of them

387 located on the North Atlantic and North Pacific margins (Xu, 2011; Puig et al., 2013; Li

388 et al., 2019).

389 The Bay of Biscay shelf break, and canyons/corrugations along it, are energetic internal

390 tide generators (Vlasenko et al., 2014). Internal tides, generated at the shelf break by

391 across-slope tidal flows (Aslam et al., 2018 and references therein), have been observed

392 as a coherent signal in the internal wave field up to $170 \mathrm{~km}$ onto the Celtic Sea shelf

393 (Inall et al., 2011).

394 A high-resolution numerical simulation of the $\mathrm{M}_{2}$ internal tide in the Whittard Canyon

395 (Aslam et al., 2018) suggests that the depth-integrated internal tide energy flux is highly

396 variable within the canyon and that the eastern branch, plus Explorer Canyon, Dangeard

397 Canyon and the flanks of Brenot Spur (Fig. 1) are key generation sites. The internal tide

398 is topographically steered along the canyon branches, but energy fluxes are directed

399 both up- and down-canyon, depending on the branch in question (Amaro et al., 2016;

400 Hall et al. 2017; Aslam et al., 2018). Close to the Whittard sandwave field, a

401 hydrographic mooring time-series accompanied by a fine-resolution 3D numerical

402 model simulation have revealed internal waves propagating north-east towards the

403 continental shelf each semi-diurnal tidal cycle together with internal solitary waves with 
up to 105 m wide amplitudes (Vlasenko et al., 2014). In Whittard Canyon itself, near-

405 bed flows are dominated by moderate to strong semi-diurnal tidal currents orientated

406 along the canyon axis (van Weering et al., 2000; Amaro et al., 2016). Ocean glider and

407 hydrographic mooring time-series along the eastern tributary canyon have resolved

408 large-amplitude (up to $150 \mathrm{~m}$ in height) semi-diurnal internal tides (Hall et al., 2017; Dr

409 Furu Mienis, NIOZ, pers com; Fig. 11), possibly transitioning to asymmetrical-shaped

410 internal bores during spring tide (Hall et al., 2017). Therefore, we postulate that internal

411 tides are the responsible mechanism for up-slope sediment transport at the canyon head,

412 and up-slope sandwave orientation observed on the Whittard outer shelf. Our results

413 confirm the long-term persistence of overflowing bottom currents on the Whittard

414 Canyon heads (Fig. 11). The net sediment transport direction is the result of a complex

415 interplay between seafloor geomorphology and local hydrodynamics, consisting of

416 internal tides, surface tidal residual currents and gravitational currents. The semi-diurnal

417 internal tides interact with the rough geomorphology of the canyon head and of the

418 surrounding steep walls, and may generate strong up-slope propagating internal bores.

419 Geomorphological evidence indicates that the effect of up-slope internal waves is

420 almost entirely dissipated on the outer shelf at the depth of $195 \mathrm{~m}$, at a distance of 5.5

$421 \mathrm{~km}$ from the western tributary head (Fig. 3, 11). The reason for which up-slope sandwaves are absent in the outer shelf adjacent to the eastern tributary is probably due to the depth-constrained action of internal waves in this specific part of the canyon. The

424 eastern tributary cuts further into the shelf than the western tributary, giving place to the 425 abrupt morphology of the head up to a depth of $195 \mathrm{~m}$ (Fig. 11). The few symmetric and 426 up-slope sandwaves in front of the eastern tributary (Fig. 3) may represent the last remnants of an old up-slope asymmetric field, which is now totally removed through the retrogressive erosion of the canyon. 


\section{$430 \quad 5.3$ Ongoing dynamics of the Whittard Canyon sandwaves}

431 There is a clear spatial variability of the contemporary sediment dynamics acting on the

432 Whittard Canyon sandwaves. The contrasting asymmetric patterns of the western and 433 eastern fields are consistent from $\mathrm{cm}$ to $\mathrm{km}$ scales, spanning ephemeral ripples to 434 megaripples and long-lived sandwaves (Fig. 8). This finding reveals a persistent 435 regional hydrodynamic regime, most probably controlled by the large-scale 436 geomorphology of the Whittard Canyon.

437 We assume that sandwaves were more active during previous lower sea level stages, 438 reflecting sediment dynamics and geomorphic patterns influenced by storm-induced and 439 tide-induced bottom currents, which during the last sea level rise progressively became 440 subordinate to the effect of the up- and down-slope flows, which currently dominate the 441 outer shelf. At the present time, the depth of the sandwaves prevents the significant 442 influence of storms, as observed in the nearby English Channel and North Sea deeper 443 than $80 \mathrm{~m}$ (e.g., Van Landeghen et al., 2012).

444 On a decadal perspective, comparative MB datasets collected 15 years apart (2000445 2015) do not suggest any measurable migration of sandwaves (Fig. S4). Carlson et al. 446 (1984) estimated an average migration rate of roughly $1 \mathrm{~cm} / \mathrm{yr}$ for the sandwaves 447 observed on the head of the Navarinsky Canyon, which in our datasets would result in 448 sub-metric migrations below the spatial resolution of our hull-mounted MB dataset (Fig. 449 S4).

450 Although the Whittard Canyon sandwaves are apparently static on a metric scale, the 451 study area can be considered as a dynamic environment. The distribution of ripples and megaripples, the observed changes in sediment composition and in the distribution of 
453 benthic communities allowed some of the small-scale processes contributing to their 454 slow migration to be inferred.

- The sand peaks at the head of the western tributary are entirely constituted of winnowed medium sands without any internal structure for the first $80 \mathrm{~cm}$ (VC_129) (Fig. 9), suggesting the recent action of strong near-bottom flows. Fresh up-slope asymmetric ripples superimposed on the peaks and the absence of any fauna (Fig. 10a), unable to settle on sediments undergoing high physical disturbance, is a further indication of recent strong hydrodynamics around the canyon heads.

- On the sandwaves stoss sides, the $40 \mathrm{~cm}$ thick upper sandy sheet laying on armoured bioclastic gravels and sands (VC_131-1, Fig. 9) currently represents the most dynamic component of the sandwaves, moving over relict deposits through the migration of megaripples, that have a similar height of $50-60 \mathrm{~cm}$. Migration of ripples and megaripples is known to influence the dynamics of the larger sandwaves they superimpose (Naqshband et al., 2014).

- Sediment dynamics become more intense near the sandwave crests, which are exclusively composed of winnowed coarse sands, with fresh asymmetric ripples and bowl-shaped depressions over a seafloor deprived of any macrobenthic fauna (BC_ 147 - Figs. 9b, 10c, d). This observation is coherent with the role of crests in enhancing and steering bottom currents along them (Smyth, 2016). In parallel, the crest area is characterized by the absence of any benthic fauna which, similarly to what was observed on the sand peak, are probably unable to settle on a habitat dominated by strong bottom current regimes (Figs. 10c, d). The SSS mosaic at the eastern site (Fig. 6) also supports an interpretation of higher current strengths around the sandwave crests, where megaripples are 

canyon head (Figs. 7c, d).

480 On the other hand, several observations illustrate that the sediment dynamics is 481 discontinuous in space and time. The accumulation of a $3 \mathrm{~cm}$ thick muddy layer on 482 some sectors of the sandwave stoss sides (Fig. 9) reflects recent bedform inactivity in 483 this area. This is further evidenced by the occurrence of faded ripples and mobile 484 benthic fauna, which tolerate the action of medium to slow current regimes alternating 485 with isolated physical disturbance events (Harris, 2014) (Fig. 10b). In addition, at a distance of $30 \mathrm{~m}$ ahead of the crest, the trough consists of bioturbated sandy sediments within a reduced muddy matrix, reflecting a lower energy environmental setting 488 (BC_148, VC_131-2, Fig. 9). This is confirmed by faded ripples observed in the area and by the occurrence of several sessile organisms (mainly anemones) colonizing the seafloor (Fig. 10e). Preserved bioturbation structures and the homogeneous sedimentary

491 facies within the first $40 \mathrm{~cm}$ of the trough sub-surface (Fig. 9) further suggests a period 492 of stability and constant low-energy hydrodynamics persisting in this region over long493 term period, with an estimated temporal scale of at least several hundreds to a few 494 thousand years (Buffoni et al., 1992). The morpho-sedimentary characteristics shown by 495 the eastern SSS mosaic support a similar interpretation, with higher current strength 496 around the sandwave crests, where megaripples are focussed, and an increasing density 497 down-slope, towards the canyon head. Low backscatter facies along most of the lee 498 sides of both western and eastern fields most probably confirm that fine sediments 499 dominate these sectors, which are sheltered by the strong currents crossing the crests in 500 up- and downslope directions respectively (Figs. 4, 5b,c,d, 6, 7b). The strongest 501 hydrodynamics acting on the Whittard Canyon sandwaves are concentrated at the 502 canyon heads and the tallest crests and extend to the stoss sides only during the most 
energetic events. Nonetheless, only the uppermost deposits of the sandwaves interact

504 with ongoing hydrodynamics and can promote bedform migration, whereas the deepest and older sediment most likely consists of inactive and relict deposits, as already described in other outer shelf settings (Goff and Duncan, 2012; Duran et al., 2018).

507 Finally, open-source EMODNET (European Marine Observation and Data Network)

508 bathymetric maps show that sandwave fields are largely present on most of the canyon

509 heads of the Celtic Margin. Although the low spatial resolution of these datasets does

510 not allow for clear quantification of sandwave asymmetry, semi-diurnal internal tides

511 are potentially an important process for enhancing up-slope sediment transport across

512 the shelf-edge of the entire Celtic margin, as already observed by Heathershaw and

513 Codd, 1985, and may be a dominant mechanism on regional scale.

515 5.4 Bowl-shaped depressions: new findings on complex morpho-sedimentary 516 patterns along sandwave crests

517 Fine scale AUV-SSS mosaics unveiled for the first time the bowl-shaped depressions.

518 These newly discovered morphologic features are present on most of the tallest crests of

519 the up-slope migrating sandwaves imaged in this study (Figs. 4, 5b). We hypothesize 520 that the sandwave crests on which two coexisting megaripples occur (Figs. 6, 7a, b) most likely represent a precursor stage of the morpho-sedimentary process having the bowl-shaped depressions as end-members (Fig. 12). The "two-fold" crest-trough-crest morphology was observed on most of the eastern sandwaves (Fig. 6, 7b) and on sectors

524 of the western field, such as the crests of smaller secondary sandwaves and far from the 525 shelf-edge, which probably represent lower energy hydrodynamics (Figs. 4, 12a). 526 Megaripples around the sandwave crests can increase their sinuosity in response to local 527 hydrodynamic forcing, organize themselves in antithetic geometry, and create circular 
528 to elongated tear-drop lobes stretched along the direction of crests (Figs. 7a, 12b, c).

529 When two antithetic megaripples merge, possibly under persisting and stronger

530 hydrodynamic conditions, they isolate residual portions of the troughs, generating

531 regular patterns of rounded bowl-shaped morphologies up to $0.6 \mathrm{~m}$ deep (Figs. 12d, e).

532 Assuming that megaripple trains migrate obliquely towards the sandwave crest, the

533 wavelength of megaripples and their orientation are responsible for the dimensions of

534 the bowl-shaped features, which resemble megaripples in both wavelength and height.

535 Despite these intriguing geomorphologies having never being observed in subaqueous

536 settings, similar spatial patterns have been described on the crests of terrestrial and

537 martian aeolian dunes controlled by bi-directional winds (Parteli et al., 2009; Courrech

538 du Pont et al., 2014). Meandering and antithetic dune crests occur under the alternate

539 action of oblique winds with divergence angles larger than $90^{\circ}$ (Parteli et al., 2009;

540 Gadall et al., 2019). Under these conditions, bedforms align with the dominant direction

541 of the two flows, optimizing the maximum gross sediment transport able to maintain

542 them (Rubin and Hunter, 1987; Courrech du Pont et al., 2014; Gadal et al., 2019).

543 Bottom currents may increase their maximum bed shear stress approaching the crests of

544 the sandwaves, and steer secondary flows directed in the ebb direction (Gadall et al., 545 2019), which could explain the along-crest elongation of some bowl-shaped depressions

546 (Fig. 11b). Moreover, field observations and 3D Computational Fluid Dynamics (CFD)

547 hint at an increased undulation of (sandwave) crest line and the action of oblique winds

548 as dominant parameters in producing deflected reverse flows, forming stretched

549 corkscrew vortices parallel to the dune (Delgado-Fernandez 2013; Jackson et al., 2013;

550 Smyth, 2016).

551 The bowl-shaped depressions around the head of the Whittard Canyon only develop on

552 the crests of the tallest sandwaves (Fig. 4), suggesting the crucial role of sandwave 
553 height which, as observed on sub-aerial settings, can alter local hydrodynamics

554 producing higher energetic regimes around the crests (Smyth, 2016; Gadal et al., 2019).

555 Where bowl-shaped depressions occur, morphologic evidence resembles some of the

556 above mentioned pre-conditioning factors, with megaripples producing a rough

557 undulation of the sandwave crest line and their orientation (the assumed direction of

558 primary flows - red arrow in Fig. 12d) forming angles from $60^{\circ}$ to $120^{\circ}$ with the

559 sandwave crests (the assumed direction of secondary flows - blue arrow in Fig. 12d).

560 Nonetheless, without the acquisition of repeated mapping and long hydrodynamic time-

561 series, and an awareness that subaqueous and subaerial mechanisms may yield

562 substantial differences, a definitive understanding of the dynamics related to these

563 features still remains unclear and speculative.

564

565

\section{CONCLUSIONS}

566 The application of multiple resolution geophysical mapping, including cutting-edge

567 marine robotics, unveiled uncommon up- and down-slope active bedform fields at the

568 head of the Whittard Canyon, displaying variability in intensity and direction of

569 sediment transport within a few hundreds of meters. The bedforms recognized in the 570 study area are sandwaves, megaripples, ripples, original sand peaks, and newly

571 discovered features along the sandwave crests, such as two-fold crests, tear-drop lobes

572 and bowl-shaped depressions.

573

574 Hydrodynamics inferred from asymmetric patterns of bedforms is consistent from $\mathrm{cm}$ 575 (ripples) to $\mathrm{m}$ (megaripples) and $\mathrm{km}$ (sandwaves) scales, suggesting a persistent regime 576 in the area maintained by the large-scale geomorphology of the Whittard Canyon head. 
578 Large-amplitude semi-diurnal internal tides transitioning to asymmetric internal bores

579 under near-critical reflection, are the suspected mechanisms for the generation of strong

580 up-canyon bottom currents, deduced to be up to $1 \mathrm{~m} / \mathrm{s}$, overflowing the canyon rim to

581 the outer shelf and generating up-slope bedform fields in the outer shelf deeper than 190

$582 \mathrm{~m}$. Shallower, up-slope currents generated in the canyon lose intensity, and downslope

583 bedforms fields are preferentially developed.

584

585 Based on fne-scale observations, the strongest hydrodynamics, able to produce sediment transport, are concentrated at the heads of the two studied tributary canyons and at the tallest sandwave crests, where spectacular trains of bowl-shaped depressions, never observed before, suggest self-organizing patterns of megaripples, in response to bidirectional current regimes interacting with a complex geomorphology.

591 Nonetheless, only the uppermost sediments of the sandwaves promote ongoing bedform

592 activity through ripples and megaripples migration, whereas the deepest sediments seem 593 to remain inactive as relict deposits.

594

595 Our results demonstrate the paramount importance of high-resolution methodologies in 596 the study of deep water settings like active bedform fields, yielding relevant insights on

597 the dynamics of complex environments, with implications in geo-hazard assessment for 598 industrial infrastructures and exchange of carbon-rich particles across shelf/slope fronts.

\section{$600 \quad 7 . \quad$ ACKNOWLEDGEMENTS}

601 Most of the data used in this work has been acquired in the JC125 cruise, funded by the 
602 ERC CODEMAP project (Complex Deep-sea Environments: Mapping habitat 603 heterogeneity As Proxy for biodiversity) (Grant No. 258482, PI: Dr V.A.I. Huvenne). 604 Additional data have been collected in the frame of the NERC funded CLASS 605 programme, Grant No. NE/R015953/1. We acknowledge the captain and crew of the 606 RRS James Cook for their assistance during the JC125 and JC166 expeditions. Special 607 thanks go to Tim Le Bas for processing the AUV-SSS and AUV-MB maps, and to the 608 ROV "ISIS" team for their kind cooperation during data acquisition. The $2000 \mathrm{MB}$ 609 dataset has been collected in the frame of the INFOMAR project (Integrated Mapping 610 for the Sustainable Development of Ireland's Marine Resources). We are finally 611 indebted with Dr P. Puig, for the fruitful discussions we had during the production of 612 this work, and with Dr. F. Mienis for her kindness in sharing information on 613 hydrographic mooring time-series. Gareth Carter publishes with permission of the 614 Director of the British Geological Survey (United Kingdom Research and Innovation).

615

\section{$616 \quad 8 . \quad$ REFERENCES}

617 Ahmerkamp, S., Winter, C., Janssen, F., Kuypers, M.M.M., Holtappels, M., 2015. The 618 impact of bedform migration on benthic oxygen fluxes. J. Geophys. Res. 120, 2229619 2242. doi:10.1002/2015JG003106.

620

621 Amaro, T., Huvenne, V.A.I., Allcock, A.L., Aslam, T., Davies, J.S., Danovaro, R., De 622 Stigter, H.C., Duineveld, G.C.A., Gambi, C., Gooday, A.J., Gunton, L.M., Hall, R., 623 Howell, K.L., Ingels, J., Kiriakoulakis, K., Kershaw, C.E., Lavaleye, M.S.S., Robert, 624 K., Stewart, H., Van Rooij, D., White, M., Wilson, A.M., 2016. The Whittard Canyon 625 a case study of submarine canyon processes. Prog. Oceanogr. 146, 38-57. 
627 Allen, S.E., Durrieu de Madron, X., 2009. A review of the role of submarine canyons in 628 deep-ocean exchange with the shelf Ocean Sci., 5, 607-620,. www.ocean629 sci.net/5/607/2009/

630

631 Aslam, T., Hall, R. A., Dye, S. R., 2018. Internal tides in a dendritic submarine canyon. 632 Progress in Oceanography 169, 20-32. doi:10.1016/j.pocean.2017.10.005.

633

634 Azpiroz-Zabala, M., Cartigny, M.J.B., Talling, P.J., Parsons, D.R., Sumner, E.J., Clare, 635 M.A., Simmons, S.M., Cooper, C., Pope, E., 2017. Newly recognized turbidity current 636 structure can explain prolonged flushing of submarine canyons. Science advances 3-10, 637 doi: $10.1125 /$ sciadv1700200

638

639 Berné, S., Laricolais, G., Marsset, T., Bourillet, J.F., De Batist, M., 1998. Erosional 640 offshore sand ridges and lowstand shorefaces: examples from tide- and wave-dominated 641 environments of France. Journal of Sedimentary Research 68, 540-555.

642

643 Bouysse, P., Horn, R. Lapierre, F., Le Lann, F., 1976. Etude des grands bancs de sable 644 du sud-est de la Mer Celtique, Marine Geology 20, 251-275.

645

646 Bourillet, J.F., Zaragosi, S., Mulder, T., 2006. The French Atlantic margin and deep-sea 647 submarine systems. Geo-Marine Letters 26, 311-315.

648

649 Buffoni, G., Delfanti, R., Papucci, C., 1992. Accumulation rates and mixing processes 650 in near-surface North Atlantic sediments: Evidence from C-14 and Pu-239,240 651 downcore profiles. Marine Geology 109 (1-2), 159-170. 
653 Carlson, P.R, Fischer J.M., Karl, H.A., Larrdn, C., 1984. Isopach map of Seismic Unit 654 A, youngest sedimentary sequence in Navarin basin, in Karl, H. A., and Carlson, P. R., 655 eds., Surface and Near-Surface Geology, Navafin Basin Province: results of the 198065681 field seasons: U.S. Geol. Survey Open-File Report 84-89, p. 33-38.

657

658 Carter, G.D.O., Huvenne, V.A.I., Gales, J.A., Lo Iacono, C., Marsh, L., Ougier659 Simonine A., Robert, K., Wynn, R.B., 2018. Ongoing evolution of submarine canyon 660 rockwalls; examples from the Whittard Canyon, Celtic Margin (NE Atlantic). Progress 661 in Oceanography 169, 79-88. doi: 10.1016/j.pocean.2018.02.001.

662

663 Courrech du Pont, S., Narteau, C., Gao, X., 2014. Two modes for dune orientation. 664 Geology 42-9, 743-746.

665

666 Cunningham, M.J., Hodgson, S., Masson, D.G., Parson, L.M., 2005. An evaluation of 667 along-and down-slope sediment transport processes between Goban Spur and Brenot 668 Spur on the Celtic Margin of the Bay of Biscay. Sedimentary Geology 79-1, 99-116. 669

670 Dauxois, T., Young W.R., 1999. Near Critical Reflection of Internal Waves. Journal of 671 Fluid Mechanics 390. doi: 10.1017/S0022112099005108.

672

673 Delgado-Fernandez, I., Jackson, D.W.T., Cooper, J.A.G., Baas, A.C.W., Beyers, J.H., 674 Lynch, K., 2013. Field characterization of three-dimensional lee-side airflow patterns 675 under offshore winds at a beach-dune system. Journal of Geophysical Research - Earth 676 Surface 118, 706-721. 
678 Durán, R., Guillén, J., Rivera, J., Lobo, F.J., Muñoz, A., Fernández-Salas, L.M., Acosta, 679 J., 2018. Formation, evolution and present-day activity of offshore sand ridges on a 680 narrow, tideless continental shelf with limited sediment supply. Marine Geology 397, $68193-107$.

682

683 Gadall, C., Narteau, C., Courrech du Pont, S., Rozier, O., Claudin, P., 2019. Incipient 684 bedforms in a bidirectional wind regime. Journal of Fluid Mechanics 862, 490-516. doi: 685 https://doi.org/10.1017/jfm.2018.978

686

687 Goff, J.A., Duncan, L.S., 2012. Re-examination of sand ridges on the middle and outer 688 New Jersey shelf based on combined analysis of multibeam bathymetry and backscatter, 689 seafloor grab samples and chirp seismic data. Int. Assoc. Sedimentol. Spec. Publ. 44, 690 $121-142$.

691

692 Hall, R.A., Carter, G.S., 2011. Internal tides in Monterey Submarine Canyon. Journal of 693 Physical Oceanography 41, 186-204. http://dx.doi.org/10.1175/2010JPO4471.1.

694

695 Hall, R.A., Aslam, T., Huvenne, V.A.I., 2017. Partly standing internal tides in a 696 dendritic submarine canyon observed by an ocean glider. Deep Sea Research Part I 126, $69773\{84$, doi:10.1016/j.dsr.2017.05.015.

698

699 Harris, P.T., 2014. Shelf and deep-sea sedimentary environments and physical benthic 700 disturbance regimes: a review and synthesis. Marine Geology 353, 169-184. 
702 Heathershaw, A.D., Codd, J.M., 1985. Sandwaves, internal waves and sediment 703 mobility at the shelf-edge in the Celtic Sea. Oceanologica Acta 8-4, 391-404.

704

705 Hotchkiss, F.S., Wunsch, C., 1982. Internal waves in Hudson Canyon with possible 706 geological implications. Deep-Sea Research Part I 29, 415-442.

707

708 Hopkins, J.E., Stephenson, G.R., Green, J., Inall, M.E., Palmer, M.R., 2014. Storms 709 modify baroclinic energy fluxes in a seasonally stratified shelf sea: inertial-tidal

710 interaction. Journal of Geophysical Research - Oceans 119, 6863-6883.

711

712 Inall, M., Aleynik, D., Boyd, T., Palmer, M., Sharples, J., 2011. Internal tide coherence 713 and decay over a wide shelf sea. Geophysical Research Letters 38, L23607, 714 doi:10.1029/2011GL049943.

715

716 Jackson, D.W.T., Beyers, M., Delgado-Fernandez, Irene., Baas, Andreas C.W., Cooper, 717 A. J., Lynch, Kevin., 2013. Airflow reversal and alternating corkscrew vortices in 718 foredune wake zones during perpendicular and oblique offshore winds. Geomorphology 187, 86-93. http://dx.doi.org/10.1016/j.geomorph.2012.12.037.

720

721 Jiang, W., Lin, M., 2016. Research on bilateral reverse migration of one-group seabed 722 sand waves in a small shallow shelf sea. Coastal Engineering 111, 70-82.

724 Karl, H.A., Cacchione D.A., Carlson P.R., 1986. Internal-wave currents as a mechanism 725 to account for large sand wave in Navarinsky Canyon head, Bering Sea. Journal of 726 Sedimentary Petrology 56-5, 706-714. 
728 Knaapen, M.A.F., 2005. Sandwave migration predictor based on shape information.

Journal of Geophysical Research 110, F04S11, doi:10.1029/2004JF000195

730

731 Knebel, H.J., Folger, D.W., 1976. Large sand waves on the Atlantic outer-continental 732 shelf around Wilmington Canyon, off eastern United States: Marine Geology 22, 7-I5.

733

734 Legg, S., Adcroft, A., 2003. Internal Wave Breaking at Concave and Convex

735 Continental Slopes. Journal of Physical Oceanography 33, 2224-2246.

736 https://doi.org/10.1175/1520-0485(2003)033<2224:IWBACA>2.0.CO;2

737

738 Li, M.Z., Prescott, R.H., Robertson, A.G., 2019. Observation of internal tides and 739 sediment transport processes at the head of Logan Canyon on central Scotian Slope,

740 eastern Canada. Journal of Marine Systems 193, 103-125.

741 https://doi.org/10.1016/j.jmarsys.2019.02.007.

742

743 Lo Iacono, C., Guillén, J., Puig, P., Ribó, M., Ballesteros, M., Palanques, A., Farrán, 744 M., Acosta, J., 2010. Large-scale bedforms along a tideless outer shelf setting in the 745 Western Mediterranean. Continental Shelf Research 30, 1802-1813.

746

747 Mulder, T., Zaragosi, S., Garlan, T., Mavel, J., Cremer, M., Sottolichio, A., Sénéchal, 748 N., Schmidt, S., 2012. Present deep-submarine canyons activity in the Bay of Biscay 749 (NE Atlantic). Marine Geology 295-298, 113-127.

750 
751 Naqshband, S., Ribberink, J.S., Hurther, D., Hulscher, S.M.J.H., 2014. Bed load and

752 suspended load contributions to migrating sand dunes in equilibrium. Journal of

753 Geophysical Research - Earth Surface 119, 1043-1063, doi:10.1002/2013JF003043.

754

755 Pantin, H.M., Evans, C.D.R., 1984. The Quaternary history of the central and 756 southwestern Celtic Sea. Marine Geology 57, 259--293.

757

758 Parker, G., 1996. Some speculations on the relation between channel morphology and

759 channel-scale flow structures, in Ashworth, P.J., et al., eds., Coherent flow structures in

760 open channels: Chichester, Wiley, p. 423-459.

761

762 Parteli, E.J.R., Durán, O., Tsoar, H., Schwämmled, V., Herrmann, H.J., 2009. Dune

763 formation under bimodal winds. PNAS December 29, 2009 vol. 106 no. 52 22085-

76422089.

765

766 Paull, C., Caress, D.W., Ussler, W., Lundsten, E., Meiner-Johnson, M., 2011. High-

767 resolution bathymetry of the axial channels within Monterey and Soquel submarine 768 canyons, offshore central California. Geosphere 7-5, 1077-1101. doi: 769 10.1130/GES00636.1.

770

771 Pingree, R., 1980. Physical oceanography of the Celtic sea and English channel.

772 Elsevier Oceanography Series 24, 415-465. 
774 Pingree, R.D., Sinha, B., Griffiths, C.R., 1999. Seasonality of the European slope

775 current (Goban Spur) and ocean margin exchange. Continental Shelf Research 19, 929776975

777

778 Piper, D.J.W., Normark, W.R., 2009. Processes that initiate turbidity currents and their

779 influence on turbidites: a marine geology perspective. Journal of Sedimentary Research $780 \quad 79,347-362$.

781

782 Praeg, D., McCarron, S., Dove, D., Ó Cofaigh, C., Scott, G., Monteys, X., Facchin, L., 783 Romeo, R., Coxon, P., 2015. Ice sheet extension to the Celtic Sea shelf edge at the Last 784 Glacial Maximum. Quaternary Science Reviews 111, 107-112.

785

786 Puig, P., Greenan, B.J.W., Li, M.Z., Prescott, R.H., Piper, D.J.W., 2013. Sediment

787 transport processes at the head of Halibut Canyon, eastern Canada margin: an interplay 788 between internal tides and dense shelf-water cascading. Marine Geology 341, 14-28.

789

790 Reynaud, J.Y., Tessier, B., Berné, S., Chamley, H., de Batist, M., 1999. Tide and wave 791 dynamics on a sand bank from the deep shelf of the Western Channel approaches. Marie 792 Geology 161, 339-359.

793

794 Rovere, M., Pellegrini, C., Chiggiato, J., Campiani, E., Trincardi, F., 2019. Impact of 795 dese bottom water on a continental shelf: an example from the SW Adriatic Sea. Marine 796 Geology 408, 123-142. doi:10.1016/j.margeo.2018.12.002.

797 
798 Rubin, D.M., Hunter, R.E., 1987. Bedform Aligmment in Directionally Varying Flows.

799 Science 237, 276-278.

800

801 Scourse, J., Uehara, K., Wainwright, A., 2009. Celtic Sea linear tidal sand ridges, the

802 Irish Sea Ice Stream and the Fleuve Manche: palaeotidal modelling of a transitional

803 passive margin depositional system. Marine Geology 259, 102e111.

804

805 Sharples, J., Tweddle, J.F., Mattias Green, J., Palmer, M.R., Kim, Y.N., Hickman, A.E.,

806 Holligan, P.M., Moore, C.M., Rippeth, T.P., Simpson, J.H., et al., 2007. Spring-neap

807 modulation of internal tide mixing and vertical nitrate fluxes at a shelf edge in summer.

808 Limnology and Oceanography 52, 1735-1747.

809

810 Slootman, A., Cartigny, M.J.B., 2020. Cyclic steps: review and aggradation based

811 classification. $\quad$ Earth-Science $\quad$ Reviews $\quad 201, \quad 102949$.

812 https://doi.org/10.1016/j.earscirev.2019.102949

813

814 Smyth, T.A.G., 2016. A review of Computational Fluid Dynamics (CFD) airflow 815 modelling over aeolian landforms. Aeolian Research 22, 153-164.

816

817 Southard, J.B., Boguchwal, L.A., 1990. Bed configuration in steady unidirection water 818 flows. Part 2. Synthesis. Journal of Sedimentary Petrology 60-5. 658-679.

819

820 Van Landeghem, K.J.J., Baas, J.H., Mitchell, N.C., Wilcockson, D., Wheeler, A.J., 821 2012. Reversed sediment wave migration in the Irish Sea, NW Europe: A reappraisal of 
822 the validity of geometry-based predictive modelling and assumptions. Marine Geology

$823295-298,95-112$.

824

825 van Weering, T.C.E., Thomsen, L., van Heerwaarden, J., Koster, B., Viergutz, T., 2000.

826 A seabed lander and new techniques for long term in situ study of deep-sea near bed 827 dynamics. Sea Technology 41, 17-27.

828

829 Vlasenko, V., Stashchuk, N., Inall, M.E., Hopkins, J.E., 2014. Tidal energy conversion

830 in a global hot spot: on the 3-d dynamics of baroclinic tides at the Celtic sea shelf break.

831 Journal of Geophysical Research - Oceans 119, 3249-3265.

832

833 Xu, J.P., 2011. Measuring currents in submarine canyons: technological and scientific

834 progress in the past 30 years. Geosphere $7,868-876$.

835

\section{9. FIGURE CAPTIONS}

837 Figure 1: a) Multibeam bathymetric map of the Whittard Canyon, composed of MB 838 data belonging to NOC, INFOMAR Project (Integrated Mapping For The Sustainable

839 Development Of Ireland's Marine. Resource Programme.- Marine Institute and

840 Geologic Survey of Ireland) and EU Emodnet Project (European Marine Observation

841 and Data Network - Bathymetry Data Portal). EC: Explorer Canyon. DC: Dangeard

842 Canyon; b) bedform fields presented in this study, mapped at the heads of two tributary

843 canyons of the Whittard eastern branch (western and eastern tributaries). Ellipsoid 844 projection: WGS84. 
846 Figure 2: Schematic representation and nomenclature of the sandwave characteristics

847 used in this study: L, wavelength; L1 and L2, lee and stoss side wavelength, 848 respectively; h, dune height (with slope correction); Zc, crest depth; Z1 and Z2, trough

849 depth; Xc, X1 and X2, position of the sandwave crest and troughs along the bathymetric 850 profile; $\alpha$, slope angle.

851

852 Figure 3: Asymmetry indexes of the Whittard Canyon sandwaves, classified in upslope asymmetric (red, AI $<-0.25$ ), symmetric (white, $-0.25<\mathrm{AI}<0.25$ ), and downslope asymmetric (blue, AI > 0.25). Black dashed lines indicate the tracks of bathymetric profiles illustrated in panels 1 and 2. Arrows in bathymetric profiles reflect the direction of sediment transport deduced by sandwave asymmetry and the colour of asymmetry classes. Ellipsoid projection: WGS84.

858

Figure 4: $15 \mathrm{~cm}$ grid cell resolution AUV-SSS mosaic acquired on the western field

860 sandwaves. Lighter shades correspond to higher backscatter. The white dashed line

861 coincides with the track of the below bathymetric profile. Numbers indicate the major 862 sandwaves of this sector.

863

864 Figure 5: Enlargements of the western AUV-SSS mosaic (Figure 4) and corresponding 865 bathymetric profiles (yellow dashed lines). Lighter shades correspond to higher 866 backscatter. Orange dashed lines in 5a indicate the longitudinal axes of numbered sand 867 peaks. bsd in $\mathrm{c}$ and $\mathrm{c} 1$ : bowl-shaped depression. BS in b and d: backscatter. Low BS 868 acoustic facies are observed in figures b, $\mathrm{c}$ and $\mathrm{d}$ on the lee side and part of the trough, 869 likely indicating fine sediment areas, sheltered by strong upslope bottom currents. 870 Locations shown in Figure 4. 
872 Figure 6: $15 \mathrm{~cm}$ grid cell resolution AUV-SSS mosaic acquired on the eastern field 873 sandwaves. Lighter shades correspond to higher backscatter. The white dashed line 874 coincides with the track of the below bathymetric profile. Numbers indicate the major 875 sandwaves of this sector.

876

877 Figure 7: Enlargements of the eastern AUV-SSS mosaic (Figure 6) and corresponding 878 bathymetric profiles (yellow dashed lines). Locations shown in Figure 6. High and low backscatter (BS) acoustic facies are observed on the stoss and lee side of figure $7 \mathrm{~b}$,

880 likely indicating coarse vs fine sediment areas, respectively exposed to and sheltered by 881 downslope bottom currents.

882

883 Figure 8: Vectors of sediment transport direction deduced from sandwave (white 884 arrows) and megaripple (orange arrows) asymmetry. Criteria for defining asymmetric 885 trends are the same adopted in Figure 3. Density of megaripples (exclusively occurring 886 where orange arrows are depicted) increase downslope, towards the heads of both 887 western and eastern tributaries. Symmetric megaripples are more numerous in the eastern field, likely evolving under the bidirectional action of tidal currents at the bottom.

891 Figure 9: Enlargements of the AUV-SSS mosaic of western field (locations in Figure 4) 892 showing in a): the sand peak where the ROV-vibro-core VC_129 (red dot) was

893 retrieved; in b): the sandwave where the ROV-vibro-cores VC_131-1, VC_131-2 894 (orange and green dots, respectively) and the box-cores BC_147, BC_148 (dark and 895 light blue, respectively) were retrieved. BS stands for backscatter. Lighter shades 896 correspond to higher backscatter. Red crosses correspond to the location of ROV 
897 images showed in Figure 10. Yellow dashed lines correspond to the tracks of the below

898 bathymetric profiles. Numbers in (a) correspond to the crests along the peaks. The 899 bathymetric profile of (b) coincides with the track of the ROV dive during which the

900 vibro-cores were collected. Arrows on bathymetric profiles coincide with the location of 901 retrieved samples. Below graphs show granulometric composition and photos of the 902 cores.

903

904 Figure 10: Bathymetric profiles (same tracks of Figure 9) and video-images from ROV 905 dives on the sampled sand peak (a; Figure 9a), and on the stoss (b) crest (c, d) and 906 trough (e) of the sampled sandwave (Figure 9b). Figures 10 a, b and e correspond to the 907 exact locations where VB129, 131-1 and 131-2 have been collected respectively.

908

909 Figure 11: 3D bathymetric sketch illustrating the main hydrodynamic and sedimentary

910 processes occurring in the study area. Up-slope bottom currents dominate the outer shelf

911 adjacent to the western tributary for a depth range of 190-220 m, whereas the eastern

912 tributary, carving the outer shelf for this depth range, is dominated by downslope

913 currents, being channelized within the gullies of the canyon head. Dots on the eastern 914 canyon axis correspond to the locations where an ocean glider (red dot, Hall et al., 915 2017) and a hydrographic mooring (yellow dot, Dr Furu Mienis, pers. comm.) resolved 916 large-amplitude semi-diurnal internal tides.

917

918 Figure 12: Proposed evolutionary model of bowl-shaped depressions, originating from 919 megaripples crests laying on sandwave crests (two-fold crests, a) under the action of bi920 directional current regimes, transitioning to tear-drop lobes $(b, c)$ and to bowl-shaped 921 depressions (d), regularly spaced along the sandwave crests (e). Red arrow indicates the 
922 direction of dominating bottom currents, deduced from megaripple orientation; blue

923 arrow indicates the orientation of secondary currents, generated from the interaction of 924 current flows with the articulated morphology of sandwave crests. Lighter shades 925 correspond to higher backscatter.

926

927 Figure S1: Morphometric characteristics (wavelength, height and asymmetry) of the 928 Whittard Canyon sandwaves.

929

930 Figure S2: $25 \mathrm{~cm}$ grid cell resolution AUV-MB map of the eastern sandwave field.

931

932 Figure S3: Morphometric characteristics (wavelength, height and asymmetry) of the 933 sandwaves of western and eastern field.

934

935 Figure S4: Sandwave migration rates obtained by comparing two bathymetric grids 936 acquired 15 years apart. Note that the comparative $2000 \mathrm{MB}$ grid used to estimate 937 potential migration has a pixel resolution of $15 \mathrm{~m}$. Migrations within a distance of 938 around $20 \mathrm{~m}$, corresponding to up around $90 \%$ of measurements, are therefore 939 considered as bias, and not taken into consideration. Estimates of rates larger than $20 \mathrm{~m}$ 940 are considered as artefacts. 

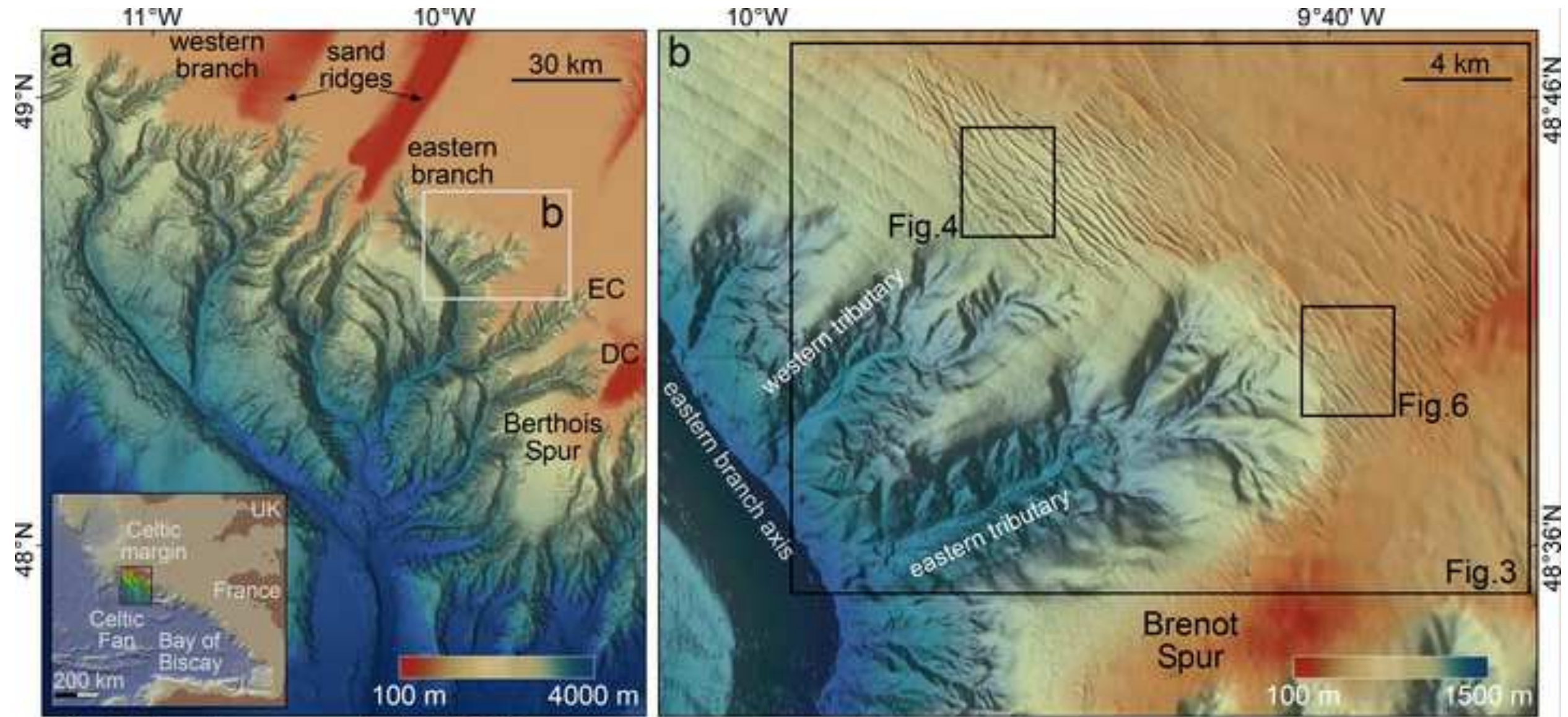

Fig.1 - Lo lacono et al., 2019 


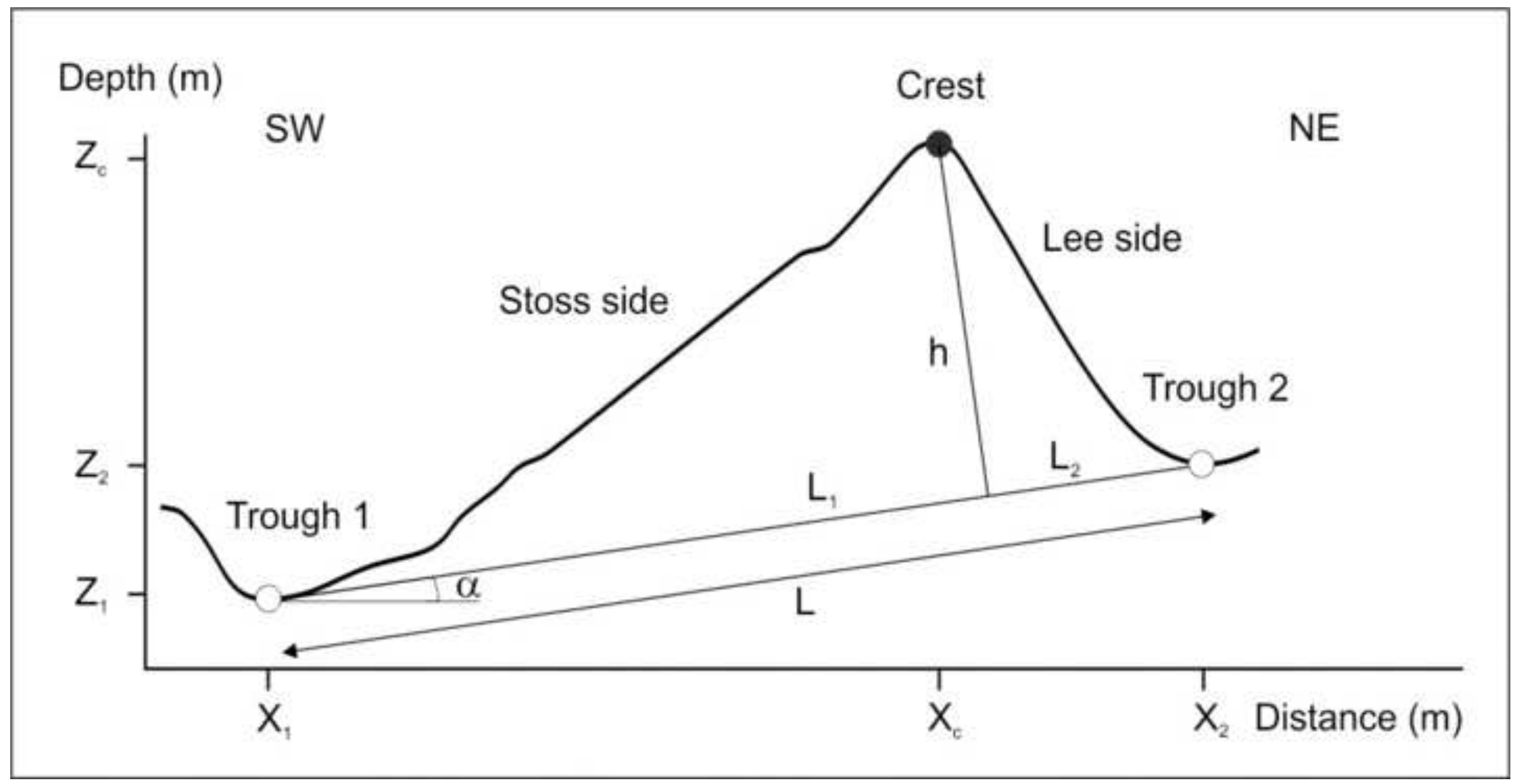



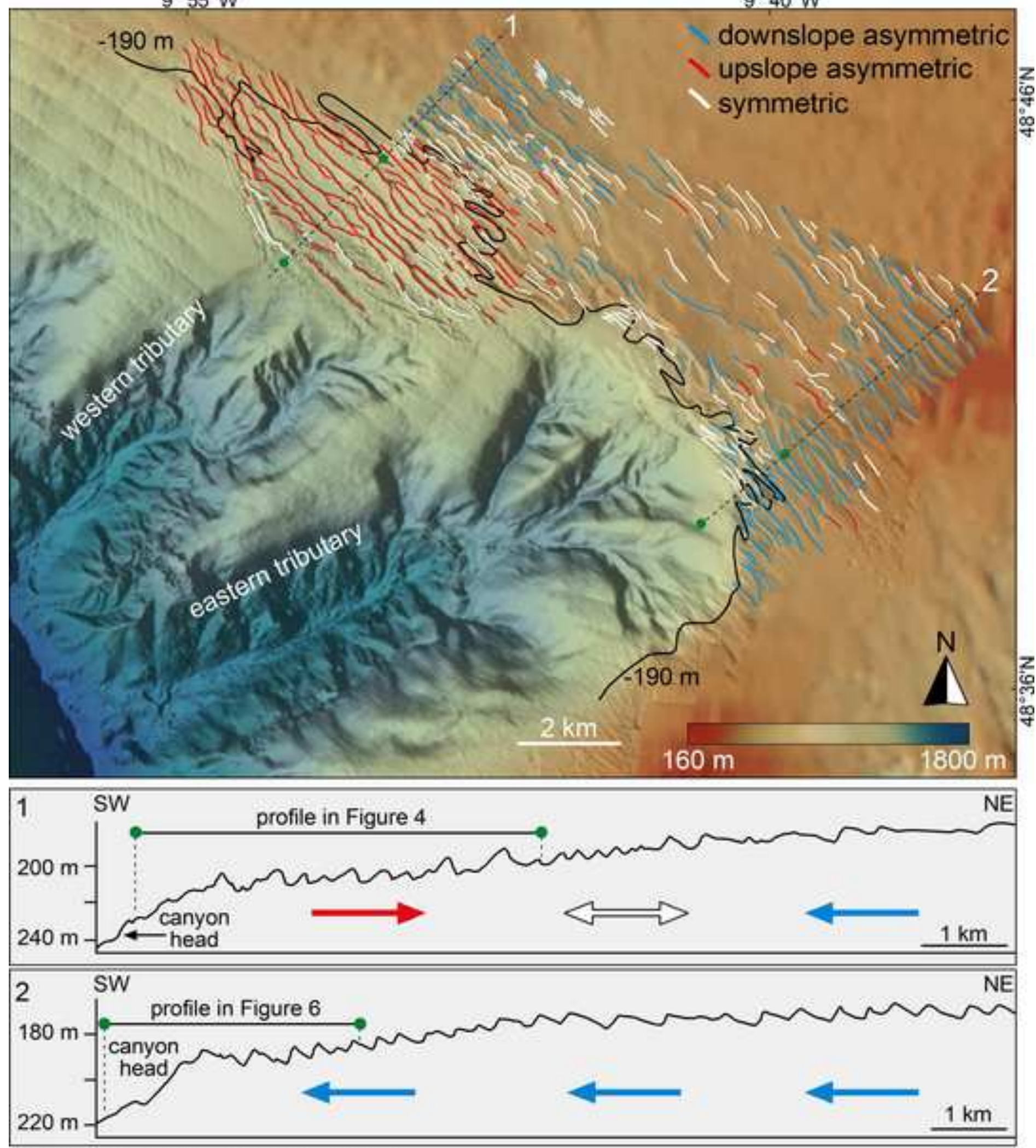

Fig. 3 - Lo lacono et al., 2019 


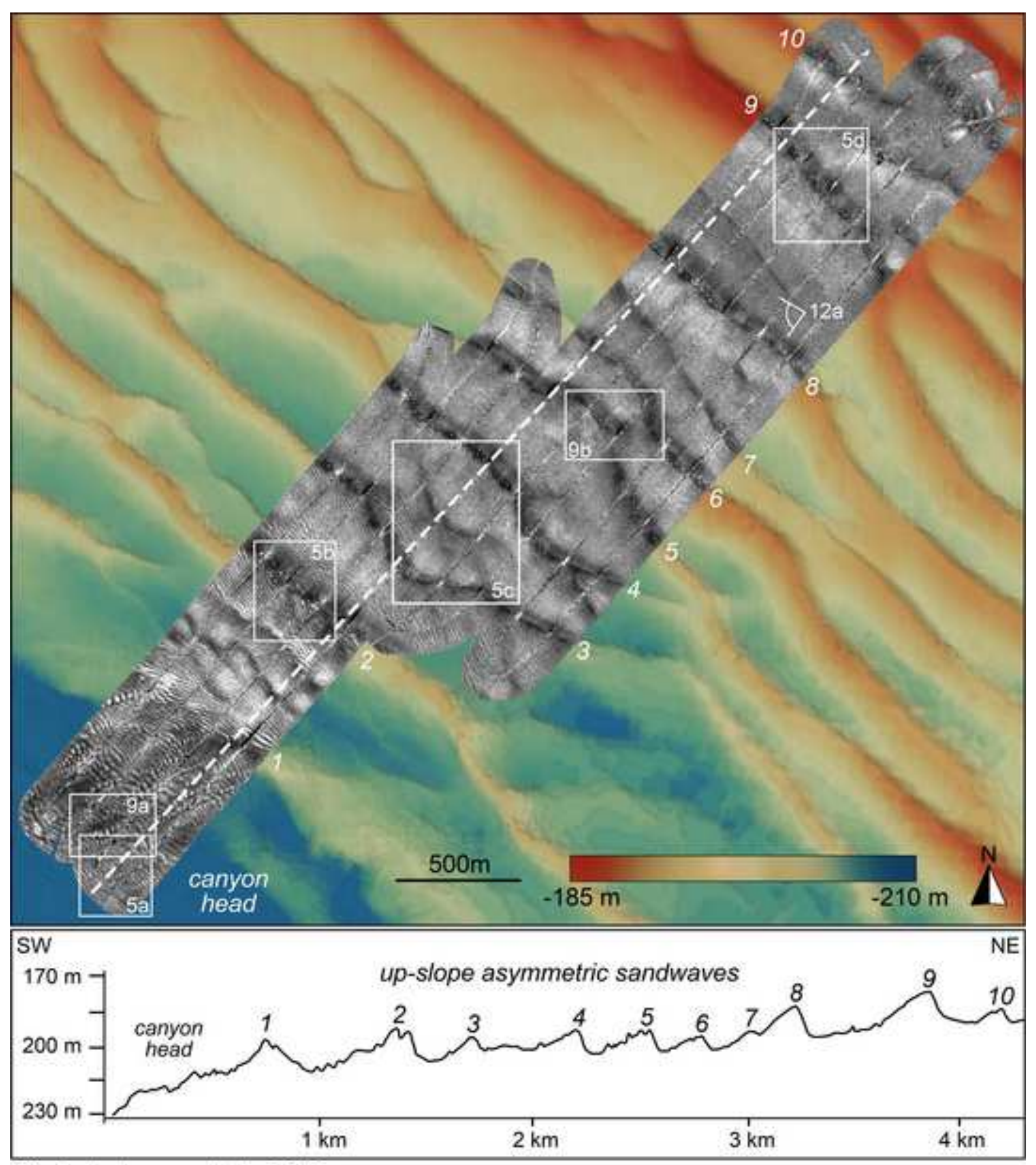

Fig.4 - Lo lacono et al., 2019

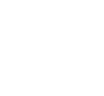

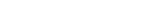

(2)



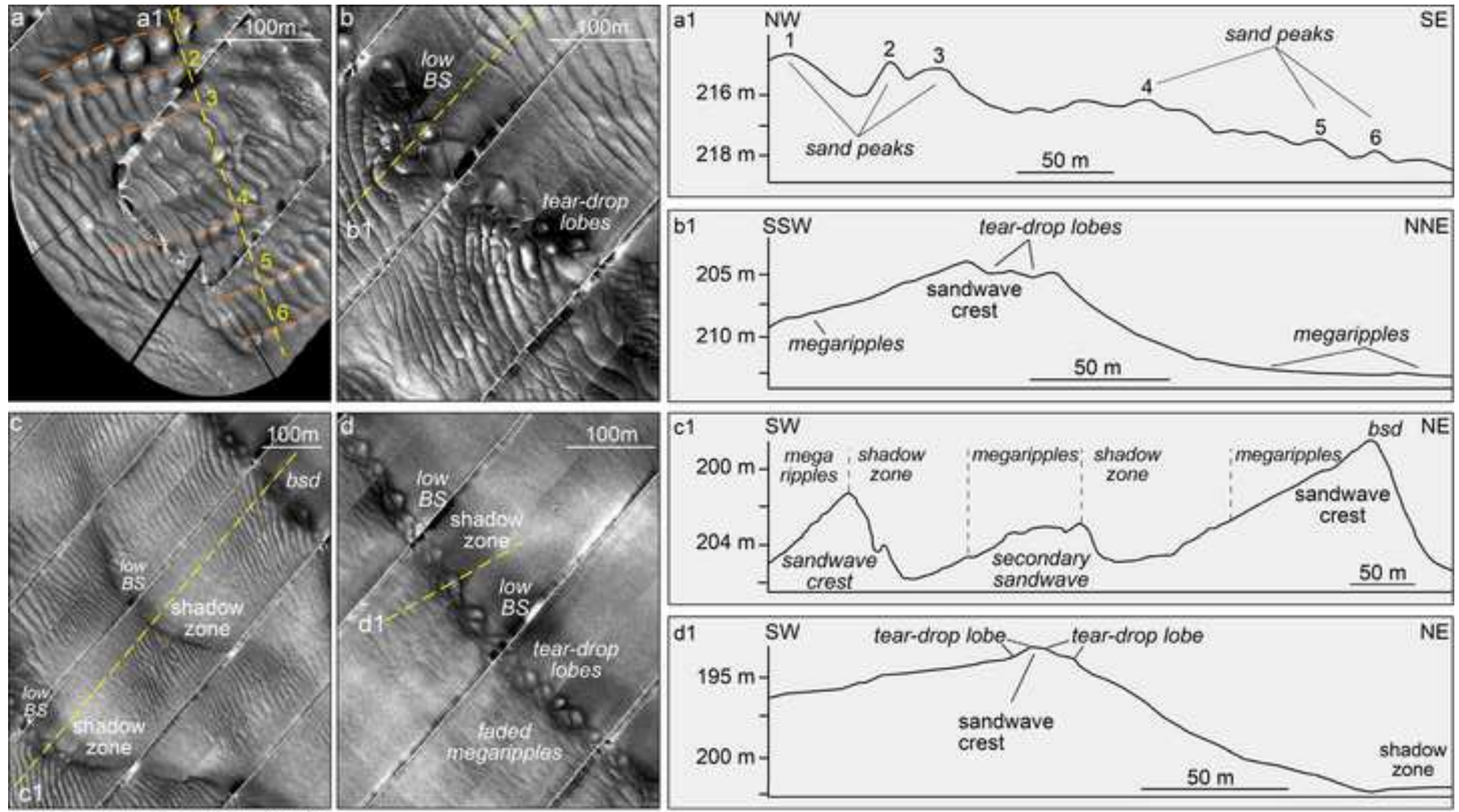

Fig.5 - Lo lacono et al., 2019 

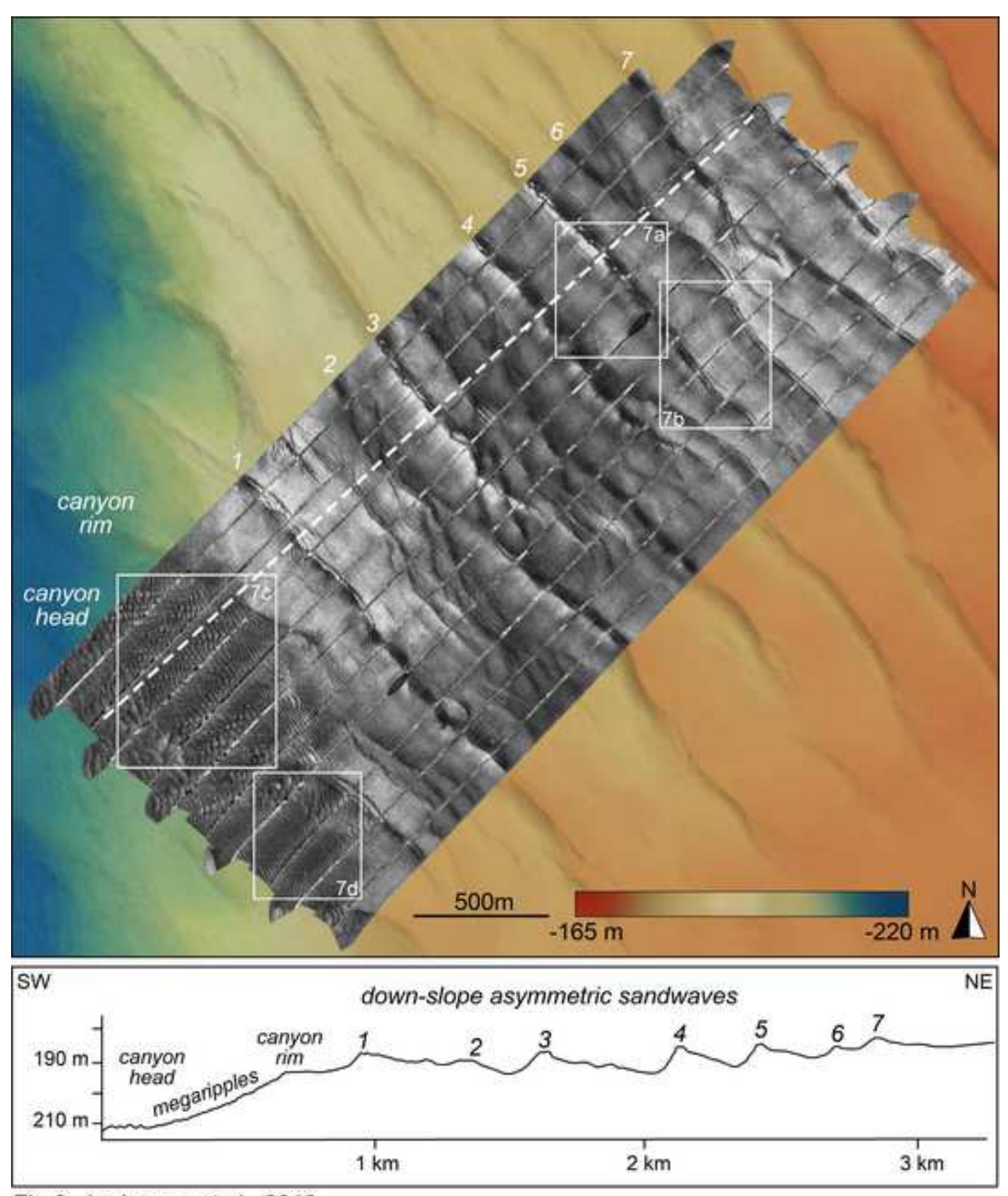

Fig.6 - Lo lacono et al., 2019

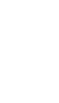

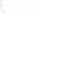



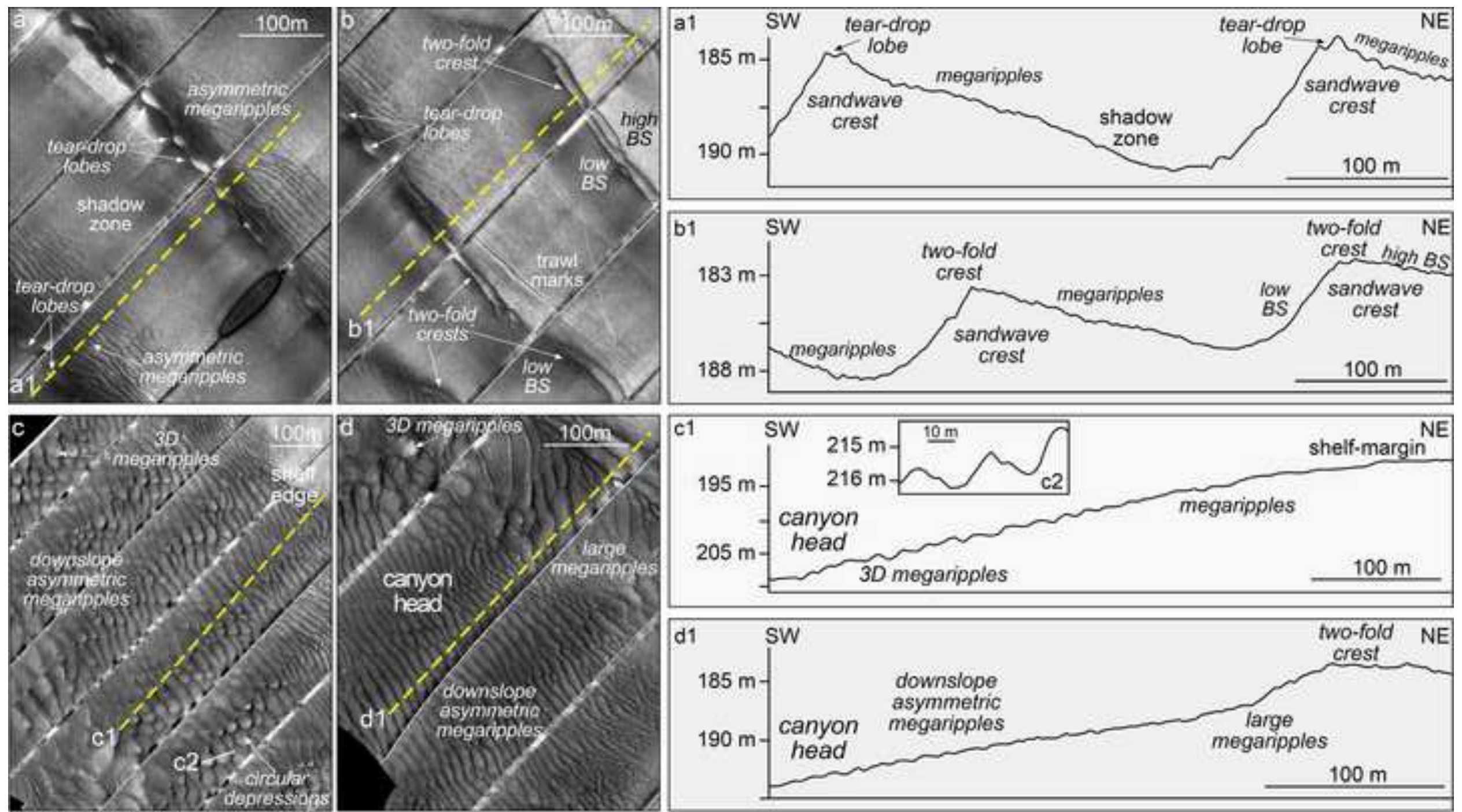

Fig.7 - Lo lacono et al., 2019 
Figure8_Lo lacono et al., 2019
Click here to download high resolution imag

Figure8_Lo lacono et al., 2019
Click here to download high resolution image
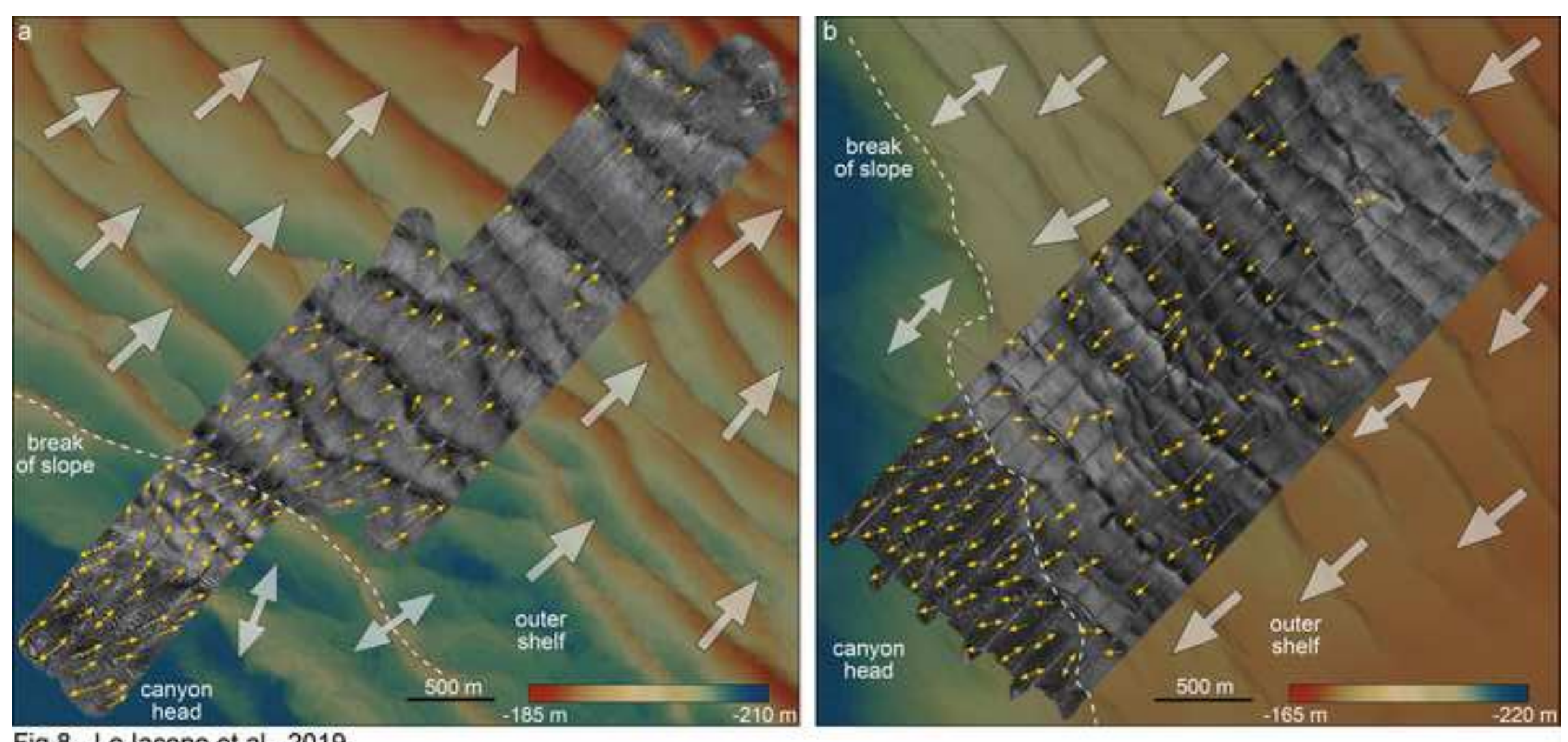

Fig.8 - Lo lacono et al., 2019 
Figure9_Lo lacono et al., 2019

Click here to download high resolution image
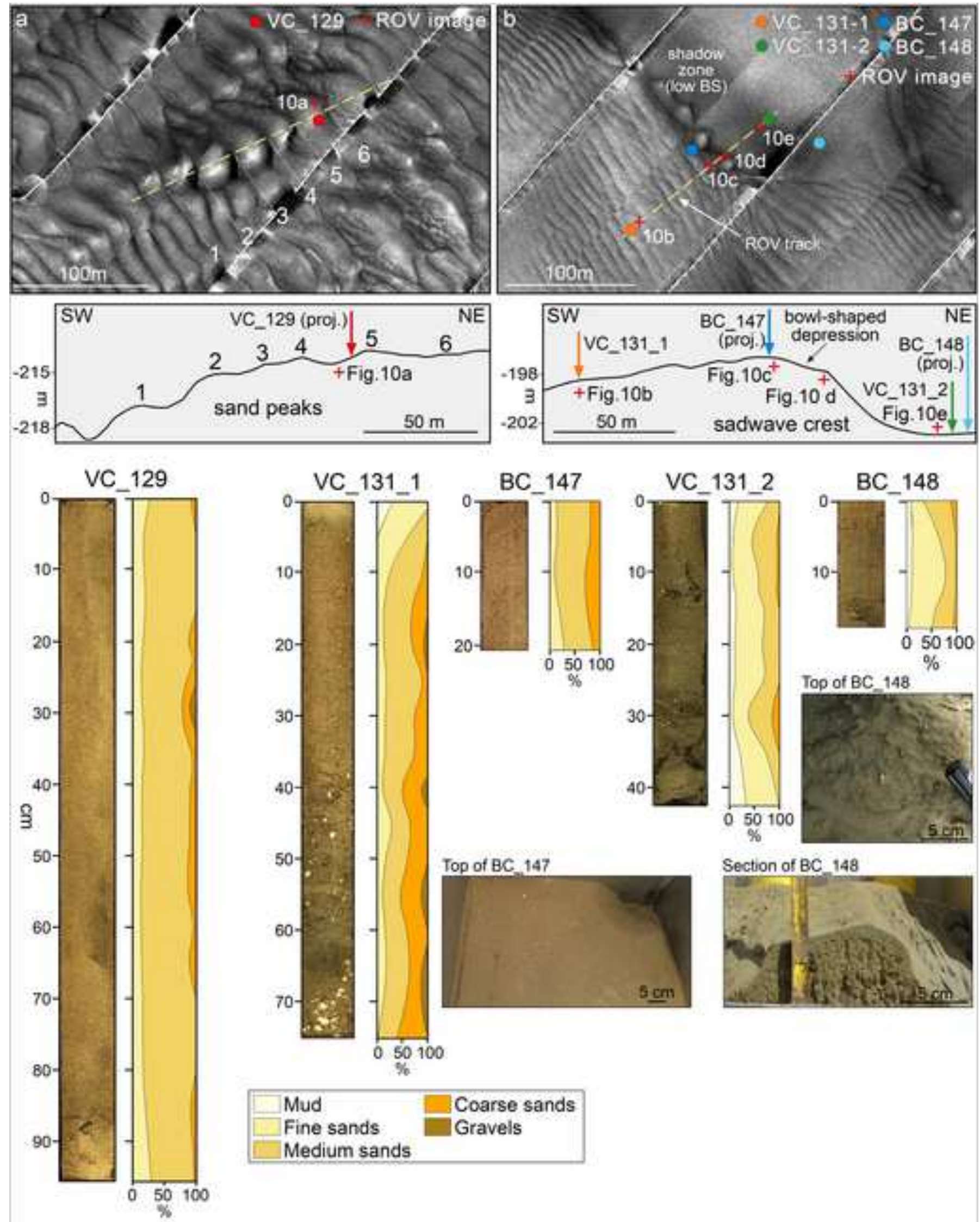

Top of BC 148

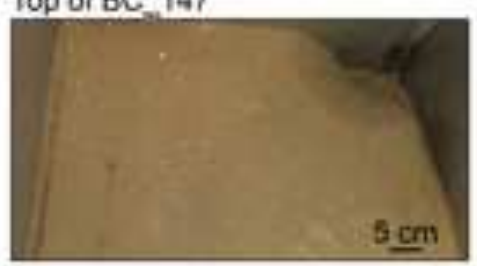

Section of BC 148

\begin{tabular}{|l|l|}
\hline Mud & Coarse sands \\
\hline Fine sands & Gravels \\
Medium sands & \\
\hline
\end{tabular}

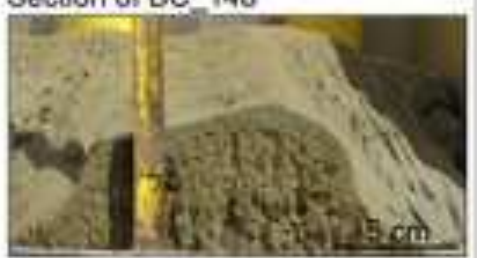

Fig. 9 - Lo lacono et al., 2019 

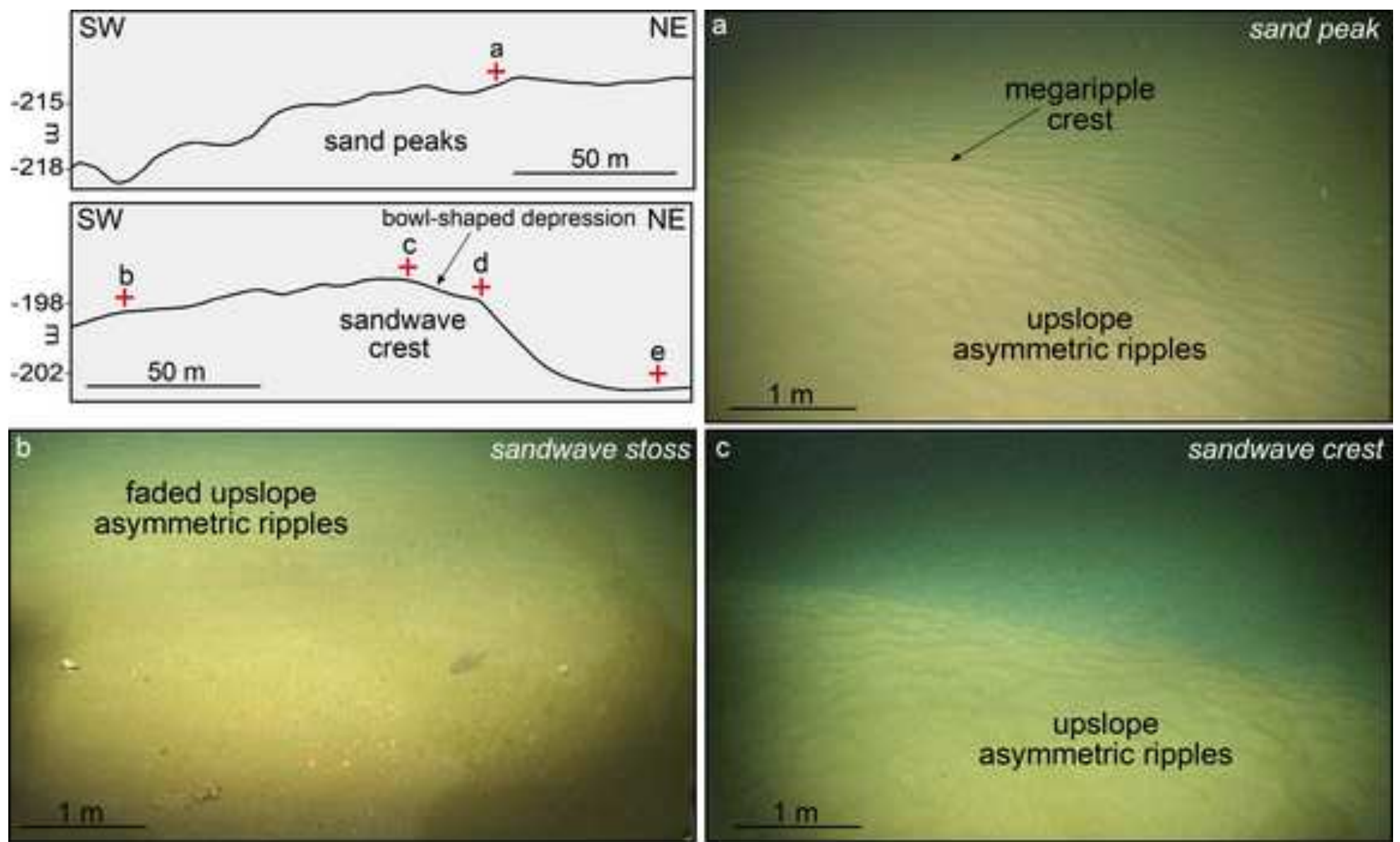

C
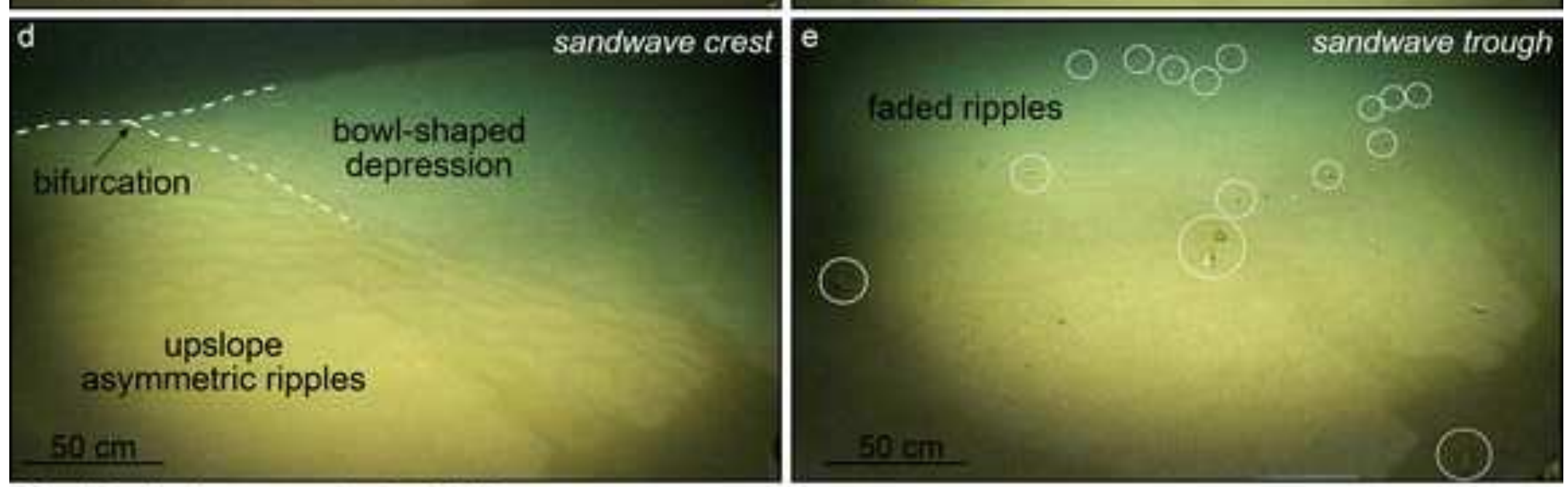

Fig.10 - Lo lacono et al., 2019

upslope

asymmetric ripples

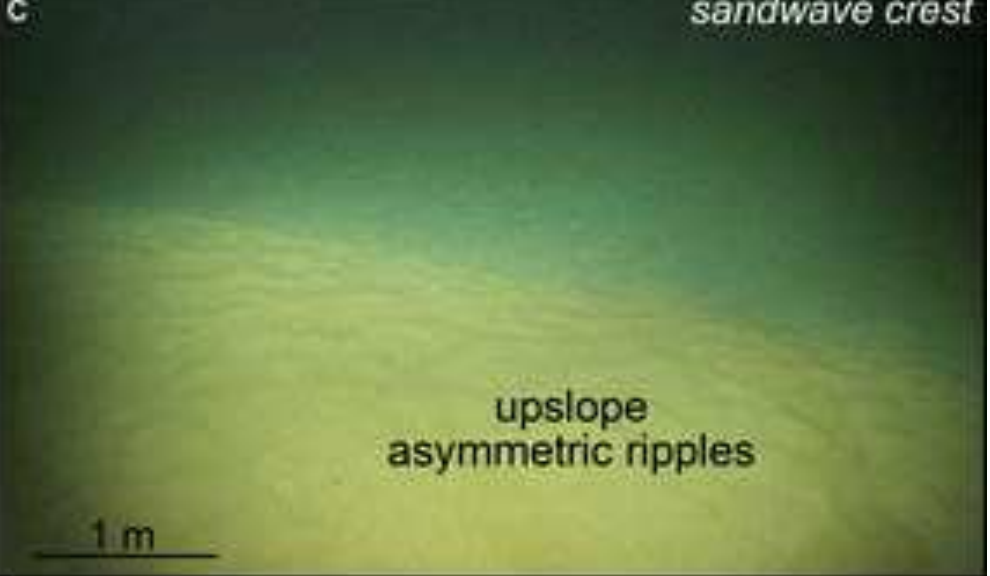




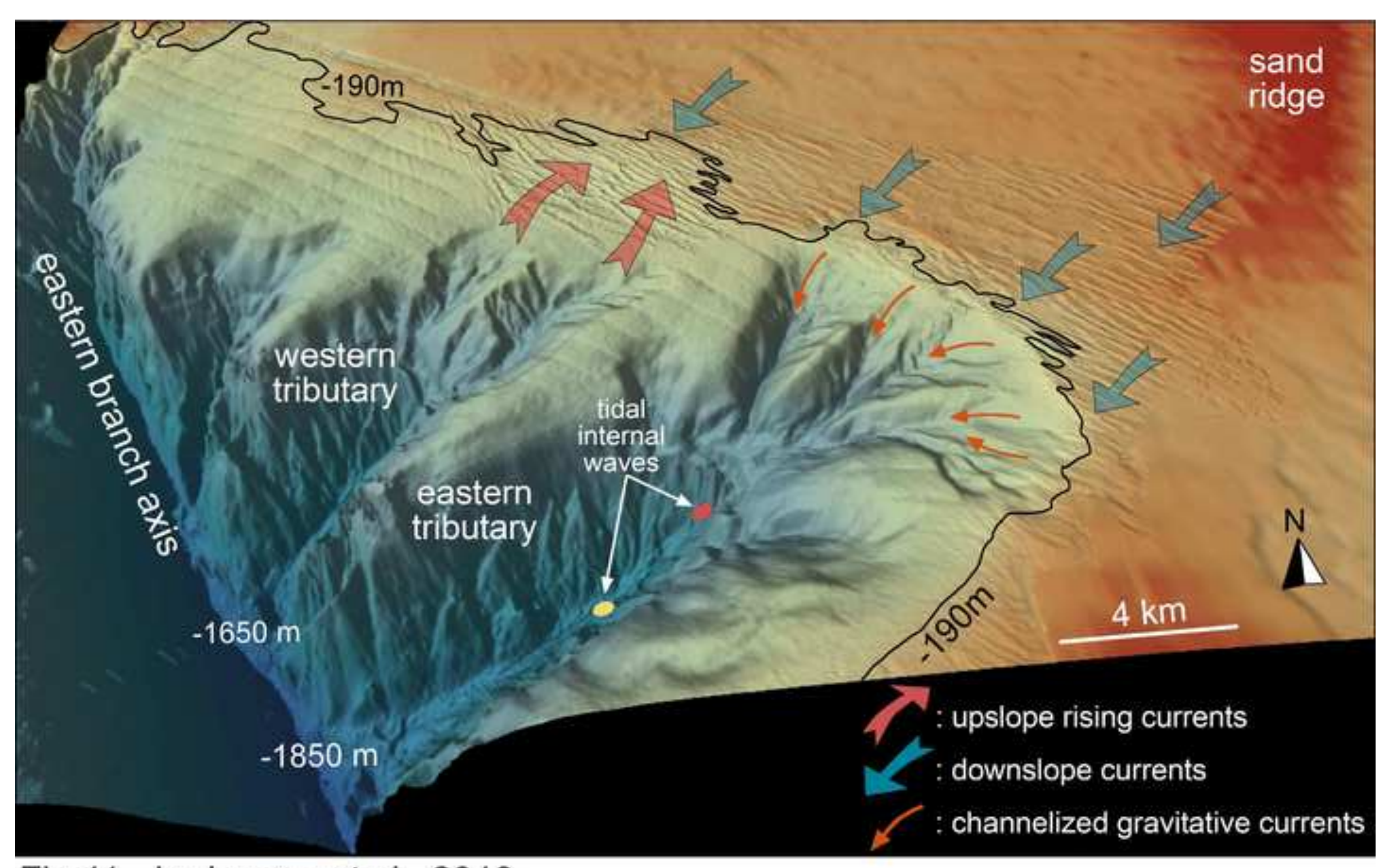

Fig.11 - Lo lacono et al., 2019 
Figure12_Lo lacono et al.,
Click here to download high resolution image
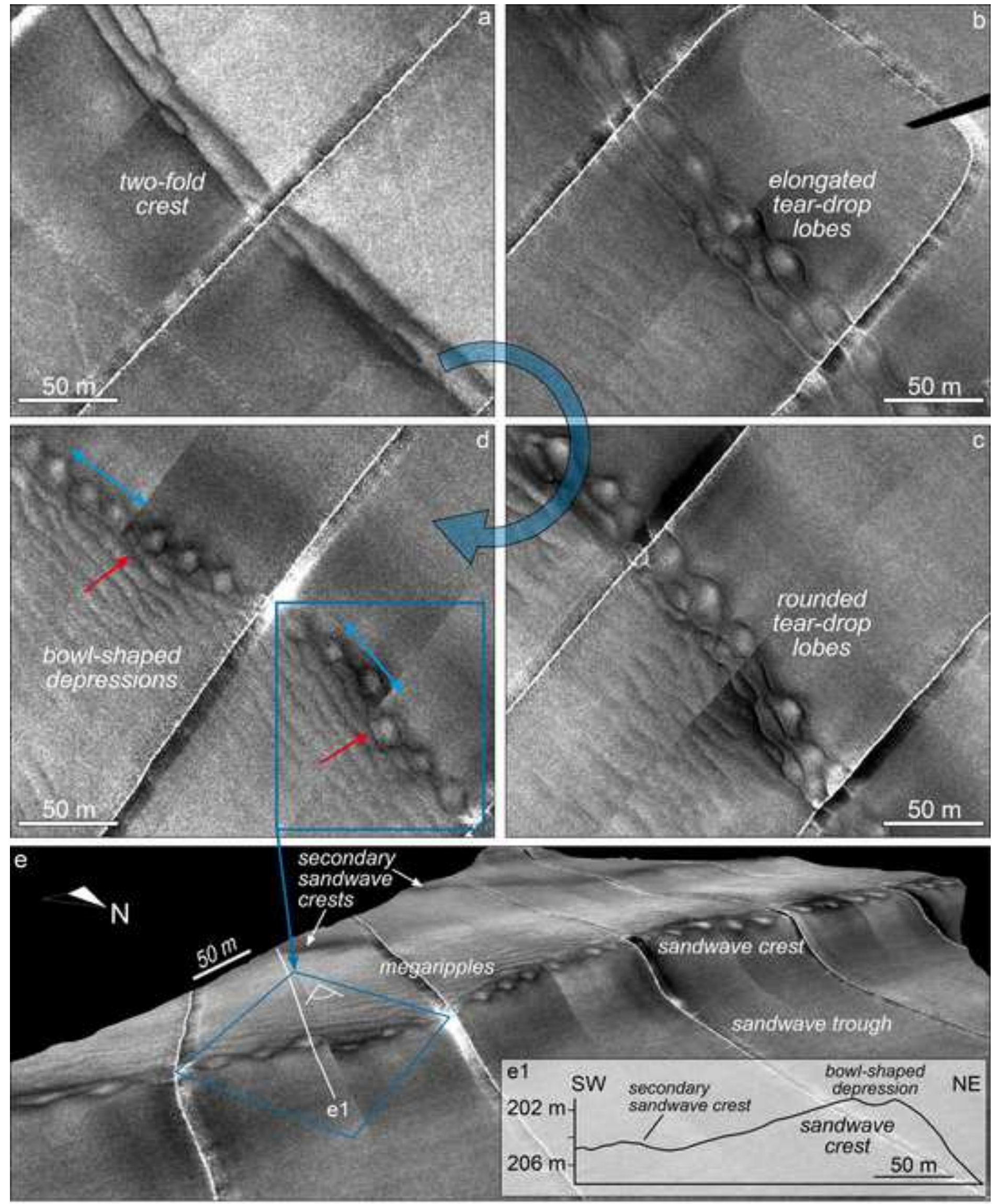

Fig.12 - Lo lacono et al., 2019 